\title{
Primary productivity and its regulation in the Pacific Sector of the Southern Ocean
}

\author{
Michael R. Hiscock ${ }^{\mathrm{a}, *}$, John Marra ${ }^{\mathrm{b}}$, Walker O. Smith Jr. ${ }^{\mathrm{c}}$, Ralf Goericke ${ }^{\mathrm{d}}$, \\ Chris Measures ${ }^{\mathrm{e}}$, Sue Vink ${ }^{\mathrm{e}}$, Robert J. Olson ${ }^{\mathrm{f}}$, Heidi M. Sosik ${ }^{\mathrm{f}}$, Richard T. Barber ${ }^{\mathrm{a}}$ \\ ${ }^{a}$ Duke University Nicholas School of the Environment and Earth Sciences, 135 Duke Marine Lab Road, Beaufort, NC 28516, USA \\ ${ }^{\mathrm{b}}$ Lamont Doherty Earth Observatory of Columbia University, Palisades, NY 10964, USA \\ ${ }^{\mathrm{c}}$ Virginia Institute of Marine Science, College of William and Mary, Gloucester Pt., VA 20362, USA \\ ${ }^{\mathrm{d}}$ Scripps Institution of Oceanography, La Jolla, CA 92093-0218, USA \\ ${ }^{\mathrm{e}}$ University of Hawaii, Honolulu, HI 96822, USA \\ ${ }^{\mathrm{f}}$ Woods Hole Oceanographic Institution, Woods Hole, MA 02453, USA
}

Accepted 1 October 2002

\begin{abstract}
We measured primary productivity in the Pacific Sector of the Southern Ocean as part of the Joint Global Ocean Flux Study. We collected data along $170^{\circ} \mathrm{W}$ from $54^{\circ} \mathrm{S}$ to $72^{\circ} \mathrm{S}$ on four cruises during the austral growing season of 1997-1998. The cruises crossed the Subantarctic Front, the Antarctic Polar Front (APF), the Southern Antarctic Circumpolar Current (ACC) Front, and the Southern Boundary of the ACC. Primary productivity and chlorophyll $a$ increased rapidly in spring, peaked in summer, and decreased rapidly in fall, following the seasonal pattern of irradiance. In early spring (October), primary productivity was $20 \mathrm{mmol} \mathrm{C} \mathrm{m}^{-2} \mathrm{~d}^{-1}$ and increased to $54 \mathrm{mmol} \mathrm{C} \mathrm{m}^{-2} \mathrm{~d}^{-1}$ within 3 weeks. During peak irradiance (December), productivity reached its maximum throughout the study area with values ranging from 33 to $93 \mathrm{mmol} \mathrm{C} \mathrm{m}^{-2} \mathrm{~d}^{-1}$ depending on station location. By February, average productivity

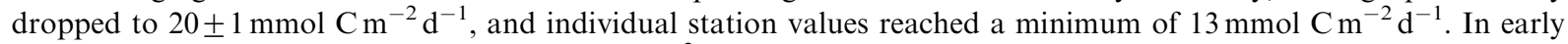
spring, chlorophyll was less than $0.5 \mathrm{mg} \mathrm{Chl} \mathrm{m}^{-3}$ throughout the study area. In late spring and early summer, chlorophyll values were between 0.15 and $1.5 \mathrm{mg} \mathrm{Chl} \mathrm{m}^{-3}$ depending on station location. By late summer, chlorophyll decreased to less than $0.3 \mathrm{mg} \mathrm{Chl} \mathrm{m}{ }^{-3}$ across the study region. Highest absolute values of productivity and biomass occurred near the southward-propagating $\mathrm{Si}$ gradient $\left(\Delta \mathrm{Si}_{\max }\right)$. A spatial gradient in photosynthetic performance correlated with $\Delta \mathrm{Si}_{\text {max }}$ : photosynthetic performance was elevated in low silicic acid waters (less than $10 \mu \mathrm{M}$ ) to the north of $\Delta \mathrm{Si}_{\max }$ and was depressed in high silicic acid waters (greater than $30 \mu \mathrm{M}$ ) to the south of $\Delta \mathrm{Si}_{\max }$. Photosynthetic performance also was correlated with iron-enrichment response: when photosynthetic performance was low, iron-enrichment response was high, and when photosynthetic performance was high, iron-enrichment response was low. These results suggest that phytoplankton were iron sufficient north of $\Delta \mathrm{Si}_{\max }$ and iron limited south of $\Delta \mathrm{Si}_{\max }$. We argue that the southward-traveling $\Delta \mathrm{Si}_{\max }$, the $\mathrm{APF}$, and the location of upwelling, iron-rich Upper Circumpolar Deep Water (UCDW) define three regions with differing iron sufficiency. Furthermore, we suggest that a winter recharge of upwelled, iron-rich UCDW within the Antarctic and Southern ACC Zones provides enough iron to support a diatom bloom that annually propagates poleward across the Antarctic and Southern ACC Zones to the Southern
\end{abstract}

\footnotetext{
*Corresponding author. Tel.: + 1-252-504-7641; fax: + 1-252-504-7648.

E-mail address: hiscock@duke.edu (M.R. Hiscock).
} 
Boundary of the ACC, where the absence of UCDW prevents the bloom's progression into the Subpolar Regime. (C) 2003 Elsevier Science Ltd. All rights reserved.

\section{Introduction}

A large proportion of the nutrients that reach the surface of the modern Southern Ocean are returned to depth unused. This relatively inefficient nutrient utilization, in combination with the fact that the Southern Ocean comprises the greatest geographic extent of nutrient-rich surface waters on earth, has prompted the idea that the Southern Ocean is pivotal in the global partitioning of $\mathrm{CO}_{2}$ between the atmosphere and the ocean. Knox and McElroy (1984) and Sarmiento and Toggweiler (1984) proposed that increased nutrient utilization through an increase in the efficiency of the Southern Ocean biological pump could explain lower $\mathrm{CO}_{2}$ levels during ice-ages. Martin (1990) further postulated that 50-fold higher aeolian Fe supplies to the Southern Ocean during the last glacial maximum could have resulted in the stimulation of enough new productivity to draw down atmospheric $\mathrm{CO}_{2}$ from 280 to less than $200 \mathrm{ppm}$.

More recent circulation and mixing models predict that the net effect of increased nutrient utilization on atmospheric $\mathrm{CO}_{2}$ would be much less than Martin (1990) calculated (Joos et al., 1991; Peng and Broecker, 1991; Sarmiento and Orr, 1991; Kurz and Maier-Reimer, 1993), demonstrating that a more efficient Southern Ocean biological pump alone cannot explain lower $\mathrm{CO}_{2}$ levels during ice-ages (see Siegenthaler and Wenk, 1984; Francois et al., 1997; Stephens and Keeling, 2000; Watson et al., 2000). Still, many current theories seeking to explain lower $\mathrm{CO}_{2}$ levels during ice-ages include higher Southern Ocean primary productivity as an integral component (Moore et al., 2000; Sigman and Boyle, 2000). This ongoing discussion of Southern Ocean nutrient utilization (Keeling and Visbeck, 2001; Sigman and Boyle, 2001) underscores the importance of understanding how the efficiency of nutrient use is regulated and whether it has changed in the recent geologic past (Broecker, 1982; Toggweiler and Sarmiento, 1985).

The Antarctic Polar Frontal Zone (APFZ) program of US Joint Global Ocean Flux Study (JGOFS) investigated the Pacific Sector of the Southern Ocean along $170^{\circ} \mathrm{W}$ from $54^{\circ} \mathrm{S}$ to $72^{\circ} \mathrm{S}$. Four cruises crossed through three physical fronts, one chemical front, a receding ice edge, and the Southern Boundary of the Antarctic Circumpolar Current (ACC) (Fig. 1). Because these features separate water masses that have distinct temperature, salinity, oxygen, macro-, and micronutrient properties, understanding their location, nomenclature, and dynamics is essential for assessing the biogeochemistry of the Southern Ocean (Tréguer and Jacques, 1992; Longhurst, 1998).

The three physical fronts divide the circumpolar regions and are characterized by concentrated shoaling of deep waters within the eastwardflowing ACC. The northernmost front within our study region is the Subantarctic Front (SAF). Along $170^{\circ} \mathrm{W}$ (our study transect), the mean position of the SAF is $57^{\circ} \mathrm{S}$ and marks where the Antarctic Intermediate Water (distinguished by a salinity minimum) is formed as it makes its rapid equatorward descent to depths near $1000 \mathrm{~m}$ (Fig. 2). The front separates the Subantarctic Zone to the north and the APFZ to the south. The second front in our study region, the Antarctic Polar Front (APF), has a mean position near $61^{\circ} \mathrm{S}$. The APF marks the northern terminus of the surface-layer temperature minimum and separates the APFZ from the Antarctic Zone (Fig. 2).

Further south, the third front within the ACC, is the Southern ACC Front (SACCF). The SACCF has a mean position near $64^{\circ} \mathrm{S}$ and separates the Antarctic Zone to the north from the Southern ACC Zone to the south. The SACCF also marks the position where the core of poleward travelling Upper Circumpolar Deep Water (UCDW) begins to shoal above $500 \mathrm{~m}$ (Fig. 2). UCDW is relatively old water supplied primarily from the eastern South Pacific Ocean and western Indian Ocean 


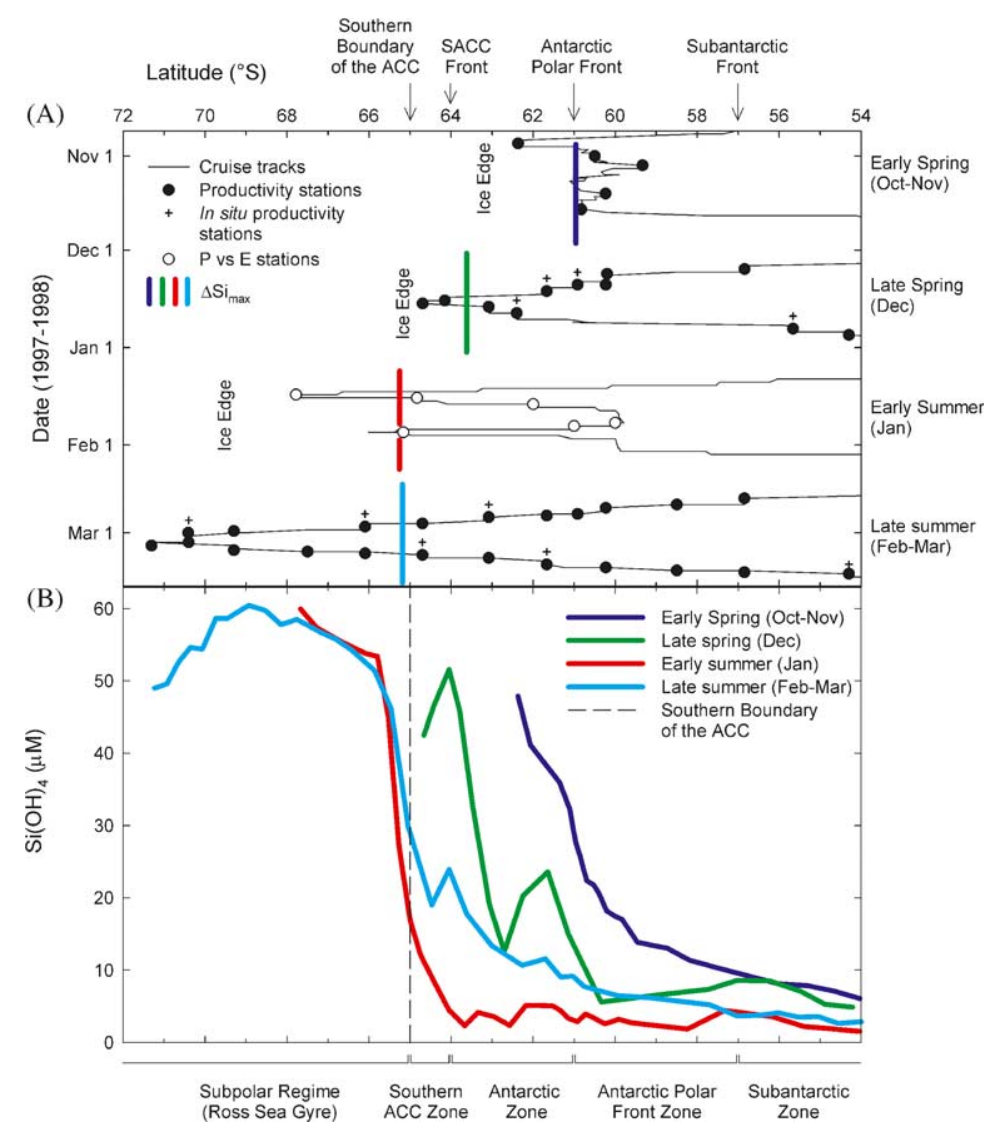

Fig. 1. (A) Time vs. space plot of the cruise tracks, and the location of on-deck productivity, in situ productivity, and photosynthesis vs. irradiance stations. Black solid lines represent cruise tracks. Vertical colored lines indicate the position where change in silicic acid concentration divided by change in latitude is maximal $\left(\Delta \mathrm{Si}_{\max }\right)$; the color of the lines corresponds to the cruises depicted in Fig. $1 \mathrm{~B}$. The location of the seasonal ice for the first three cruises is indicated; it receded beyond the study region by early February. (B) Mean underway silicic acid concentrations for each of the four cruises. The $\Delta \mathrm{Si}_{\max }$ moves to the south in the spring and halts near the Southern Boundary of the ACC (dashed line).

and is characterized by an oxygen minimum and a nutrient maximum (Callahan, 1972; Whitworth and Nowlin, 1987; Park et al., 1993). Below the UCDW is the Lower Circumpolar Deep Water (LCDW), which is comprised of slightly warmer, salty, oxygen-rich and nutrient-poor North Atlantic Deep Water (Patterson and Whitworth, 1990; Park et al., 1993).

The single boundary in our study region, the Southern Boundary of the ACC, has a mean position near $65^{\circ} \mathrm{S}$. The Southern Boundary of the ACC is the poleward limit of the circumpolar flow of the ACC and separates the Southern ACC Zone to the north from the Subpolar Regime to the south (Orsi et al., 1995). It is also a critical boundary between the poleward-shoaling UCDW within the ACC (Fig. 2) and the more quiescent waters (weaker geostrophic shear) of the Subpolar Regime (Orsi et al., 1995). North of the Southern Boundary of the ACC, UCDW shoals and mixes with the Antarctic Surface Water (Fig. 2). South of the Southern Boundary of the ACC (Subpolar Regime), no evidence of UCDW is found, and the water column consists almost entirely of LCDW and Antarctic Bottom Water (Whitworth and Nowlin, 1987; Patterson and Whitworth, 1990). At $170^{\circ} \mathrm{W}$, the Subpolar Regime is also called the Ross Sea Gyre. Further south, and beyond the 


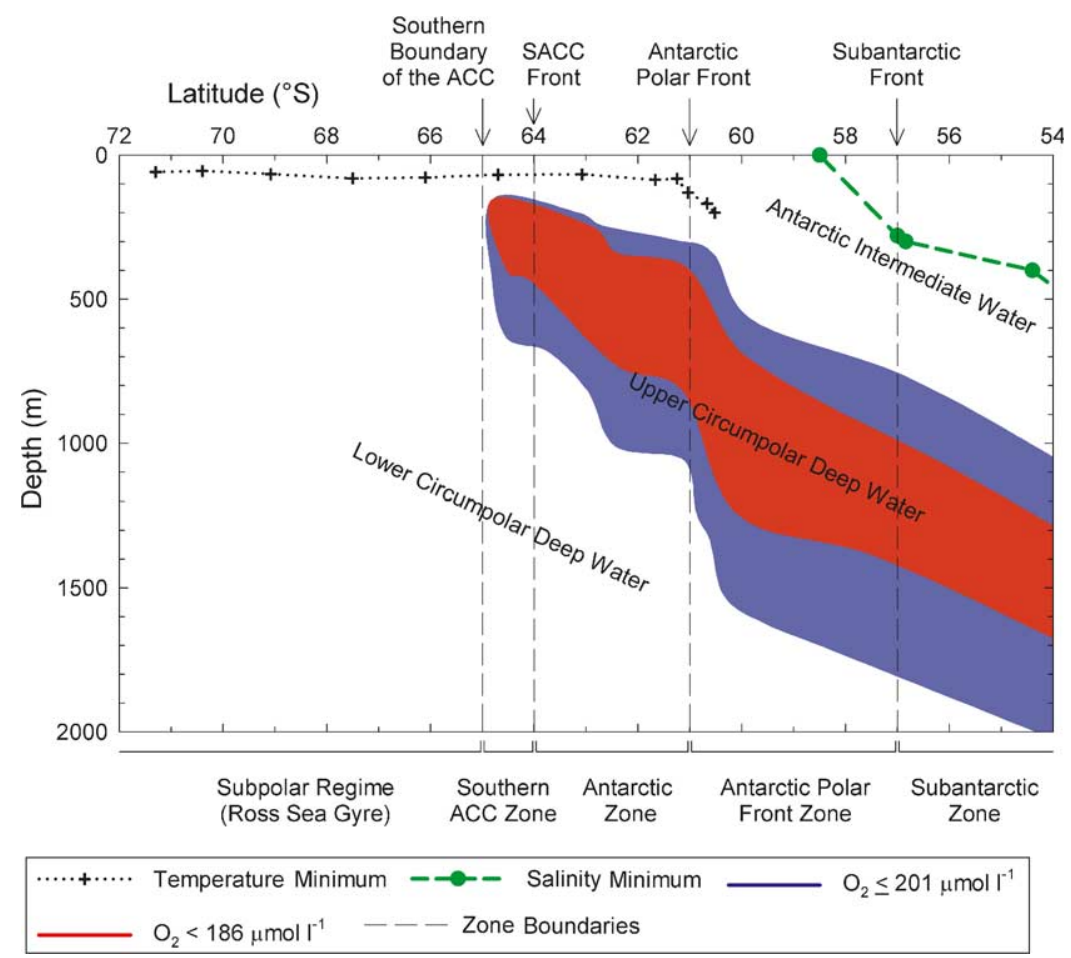

Fig. 2. The location of the fronts along $170^{\circ} \mathrm{W}$ during the austral summer of 1997-1998 (Smith et al., 2000b) was consistent with the mean positions identified by Orsi et al. (1995). The SAF marks where Antarctic Intermediate Water (salinity minimum) is formed as it makes its rapid equatorward descent to depths near $1000 \mathrm{~m}$. The APF marks the northern terminus of the subsurface layer temperature minimum. The UCDW is defined as waters with $\mathrm{O}_{2} \leqslant 201 \mu \mathrm{moll}^{-1}$ at density values of $27.35 \mathrm{~kg} \mathrm{~m}^{-3}<\sigma_{0}<27.75 \mathrm{~kg} \mathrm{~m}^{-3}$ (Orsi et al., 1995). The SACCF marks the position where the core of poleward-travelling UCDW begins to shoal above $500 \mathrm{~m}$. The core of UCDW (colored in red) has $\mathrm{O}_{2}<186 \mu \mathrm{moll}^{-1}$. The Southern Boundary of the ACC marks the location where the poleward-shoaling UCDW is no longer identifiable.

scope of this paper, lie relatively shallow shelf waters influenced by the Antarctic continental margin.

In addition to the fronts and boundary described above, our study region was dominated by the seasonal retreat of ice (Smith et al., 2000b) and a southward-progressing silicic acid front (Sigmon et al., 2002). The ice edge was near $63^{\circ} \mathrm{S}$ in October and retreated south beyond the study region by February. The silicic acid front was near the APF during October, migrated southward to the Southern Boundary of the ACC in January, and remained at the Southern Boundary of the ACC through March (Fig. 1).

The coherent correlation of the fronts, boundary, and ice edge with high biomass and high primary productivity demonstrates that these physical and chemical features are involved in the regulation of primary productivity (Lutjeharms et al., 1985; Smith and Nelson, 1985; Bathmann et al., 1997; Veth et al., 1997; Tynan, 1998; Brzezinski et al., 2001). Within these features, single-factor controls on Southern Ocean photosynthetic performance and primary productivity have been relatively well documented (Fogg, 1977; Holm-Hansen et al., 1977; Cushing, 1981; El-Sayed and Taguchi, 1981; Jacques and Minas, 1981). Temperature (Jacques, 1989), seasonal irradiance (Nelson and Smith, 1991), mixing (Mitchell and Holm-Hansen, 1991), macronutrients (Nelson and Tréguer, 1992; Sullivan et al., 1993), micronutrients (Martin et al., 1990; de Baar et al., 1995), and grazing (Banse, 1996) all have been identified as factors that regulate primary 
productivity at various locations and times. How these various regulating factors operate in combination, in the complex physical domain of the Southern Ocean, to produce a highly varying spatial and temporal mosaic of productivity, however, is poorly understood.

We examined primary productivity from 44 stations collected on four cruises that spanned the austral growing season and traversed the circumpolar zones of the Southern Ocean along $170^{\circ} \mathrm{W}$. We found low and variable productivity that fit roughly within the seasonal pattern described by earlier investigators (Hart, 1942; Ryther, 1963; Currie, 1964; Burkholder and Burkholder, 1967), but measurements of photosynthetic performance in conjunction with iron-enrichment experiments revealed a different and more complex story. The spatial and temporal pattern of iron-enrichment response and the variability of ambient photosynthetic performance indicated the existence of three productivity regions. These three regions differ in their seasonal cycles, their regulation of primary productivity, and their likely productivity response to past and future iron enrichment.

\section{Methods}

\subsection{Cruise plan}

Four JGOFS cruises aboard R/V Roger Revelle were conducted along $170^{\circ} \mathrm{W}$ during the austral growing season of 1997-1998. Measurements were taken from $54^{\circ}$ to $72^{\circ} \mathrm{S}$ across the SAF, the APF, the SACCF, and the Southern Boundary of the ACC (Fig. 1a). Two cruises, in early spring (October-November 1997) and early summer (January 1998), obtained high-resolution surveys, and two cruises, in late spring (December 1997) and late summer (February-March 1998), concentrated on detailed process studies carried out at stations along $170^{\circ} \mathrm{W}$ (Fig. 1a).

\subsection{Physical and chemical observations}

Vertical profiles of nutrients, salinity and temperature were measured at each station (Morrison et al., 2001). We defined mixed-layer depth
$\left(Z_{\text {mix }}\right)$ as the depth at which subsurface $\sigma_{t}$ differed from surface $\sigma_{t}$ by 0.01 (Brown and Landry, 2001a). Critical depth $\left(Z_{\mathrm{Cr}}\right)$ was calculated with a single alteration of Nelson and Smith's (1991) reformulated Sverdrup (1953) equation. Because values of net photocompensation irradiance can vary between 5 and $35 \mu \mathrm{mol}$ quanta $\mathrm{m}^{-2} \mathrm{~s}^{-1}$ (D. Nelson, personal communication), we use the mean value of $20 \mu \mathrm{molquanta} \mathrm{m}^{-2} \mathrm{~s}^{-1}$ in the reformulated Sverdrup equation (Sverdrup, 1953; Nelson and Smith, 1991). Irradiance $(E)$ measurements refer to photosynthetically active radiation (PAR) between 400 and $700 \mathrm{~nm}$. The downwelling irradiance present just above the surface of the ocean, $E_{\mathrm{d}}\left(0^{+}\right)$, was measured with a flat, Biospherical Instruments ${ }^{\circledR}$ cosine collector on the ship's mast. When ship observations were not available, $E_{\mathrm{d}}\left(0^{+}\right)$was estimated using the Gregg and Carder (1990) clear-sky $E_{\mathrm{d}}\left(0^{+}\right)$model and percent cloud cover, determined by using nearby Satlantic ${ }^{\circledR}$ OCI-200 downwelling irradiance meters mounted on Oregon State University moorings (Abbott et al., 2000). Iron analyses were performed using the Measures et al. (1995) flow injection analysis technique.

\subsection{Chlorophyll $a$ and other pigments}

Chlorophyll $a$ was determined by fluorometric methods and by high-performance liquid chromatography (HPLC). Fresh samples were extracted in $90 \%$ acetone at $-20^{\circ} \mathrm{C}$ for $24-30 \mathrm{~h}$ (Venrick and Hayward, 1984) and quantified using a Turner Designs fluorometer (Holm-Hansen et al., 1965; Lorenzen, 1966). A complete suite of plant pigments was analyzed following the procedures described by Goericke and Repeta (1993). HPLC determinations of chlorophyll $a$ accounted for $86 \%, 64 \%, 58 \%$, and $40 \%$ of the fluorometric signal during early spring, late spring, early summer, and late summer cruises, respectively. The cause of this HPLC versus (vs.) fluorometer disagreement is unknown, but not unique to this study. In 1999 the Southern Ocean Iron RElease Experiment (SOIREE) group saw a two-fold difference between HPLC and fluorometrically determined chlorophyll $a$ (Gall et al., 2001b). The HPLC measurements reported here were 
reconfirmed by independent measurements at the University of Hawaii Department of Oceanography, suggesting that there is an unresolved factor affecting the fluorometric determinations as hypothesized by Gall et al. (2001b).

The HPLC-derived chlorophyll $a$ values are the sum of the chlorophyll pigment peaks known to be photosynthetically active, that is, chlorophyll $a$, the chlorophyll $a$ isomer, chlorophyllide $a$, and the allomerized chl $a$ 's. These values were used to calculate chlorophyll-specific productivity rates. Fluorometrically derived measurements of chlorophyll $a$ include photosynthetically active pigments, as well as some unknown actively fluorescing pigments that are not represented in the HPLC pigment peaks. Both types of pigment quantified in the fluorometrically derived measurement of chlorophyll $a$, however, attenuate light. Therefore, these measurements were used to estimate water column light attenuation (Morel, 1988). In cases where we had primary productivity measurements but no HPLC values, the fluorometric chlorophyll $a$ values were corrected to photosynthetically active HPLC chlorophyll $a$ values according to a linear regression analysis of pairs of HPLC and fluorometric measurements made from the same water bottles ( $m=0.401, b=$ $\left.-0.000913, n=106, r^{2}=0.69\right)$.

\subsection{Primary productivity}

Primary productivity was measured using radioisotope incorporation techniques (Barber et al., 1996). Stock isotope solution of $100 \mu \mathrm{Ci} \mathrm{ml}^{-1}$ was made by dissolving anhydrous crystalline sodium ${ }^{14} \mathrm{C}$-carbonate (specific activity of $55 \mathrm{mCi} \mathrm{mmol}^{-1}$ ) and $0.3 \mathrm{~g}$ of $\mathrm{Na}_{2} \mathrm{CO}_{3}$ in 1.01 of Nanopure ${ }^{\circledR}$ water. A trace-metal-clean (TMC) rosette with General Oceanics Go-Flo ${ }^{\circledR}$ sample bottles and a Kevlar cable was used for water collection (Hunter et al., 1996). Samples for in situ and on-deck primary productivity determinations were usually collected near local midnight (in situ and on-deck stations shown in Fig. 1). For each depth sampled, $280 \mathrm{ml}$ polystyrene tissue culture flasks were filled and inoculated with $\sim 10 \mu \mathrm{Ci}$ of ${ }^{14} \mathrm{C}$-carbonate. To determine the total added activity, 0.1-ml subsamples were taken from selected inoculated flasks and added directly to scintillation vials containing $0.1 \mathrm{ml}$ of beta-phenylethylamine and $5 \mathrm{ml}$ of Ecolume scintillation fluid. To determine timezero particulate ${ }^{14} \mathrm{C}$, additional bottles were filled, inoculated with ${ }^{14} \mathrm{C}$ solution, and immediately filtered (Huntsman and Barber, 1977).

For in situ incubations, flasks were mounted on clear Plexiglas ${ }^{\circledR}$ racks and lowered to the intended depth of incubation. The on-deck incubations were conducted in surface seawater-cooled, Plexiglas ${ }^{\circledR}$ incubators. Immediately after the 24-h incubation, in situ and on-deck samples were filtered through 25-mm Whatman GF/F filters with less than $200 \mathrm{~mm} \mathrm{Hg}$ of vacuum. Each filter was placed in a $7-\mathrm{ml}$ scintillation vial to which $0.5 \mathrm{ml}$ of $0.5 \mathrm{~N} \mathrm{HCl}$ were added, and after $24 \mathrm{~h}$, $5 \mathrm{ml}$ of scintillation fluid were added. After another $24 \mathrm{~h}$, samples were counted at sea in a liquid scintillation counter.

On-deck incubators were intended to reproduce $100 \%, 50 \%, 25 \%, 18 \%, 10 \%, 5 \%$, and $1 \%$ of $E_{\mathrm{d}}\left(0^{-}\right)$via neutral density screening. But simultaneous on-deck and in situ productivity measurements demonstrated that the on-deck incubators received more irradiance than was intended. On average, the $100 \%$ and $50 \% E_{\mathrm{d}}\left(0^{-}\right)$carbon uptake rates from on-deck incubations were less than those of the near-surface in situ incubations due to photoinhibition (see Fig. 5 in Smith et al., 2000a). When compared individually with in situ incubations, productivity samples from the $50 \%$ lightlevel on-deck incubator exhibited an artifact of photoinhibition or photoenhancement, depending on the daily irradiance conditions (Fig. 3). Deck incubators designed to simulate light levels deeper in the euphotic zone also saw a subsidy of irradiance that translated into photoenhancement. In order to compensate for the additional irradiance, the primary productivity data were reprocessed by ground-truthing on-deck profiles against in situ profiles obtained at the same station (Barber et al., 1997; Bradford-Grieve et al., 1997; Smith et al., 2000a).

The irradiance subsidy is due to the fact that box-shaped incubators receive irradiance from five sides and act as nearly spherical or scalar collectors of irradiance. In contrast, the ocean receives irradiance through only one surface, and 


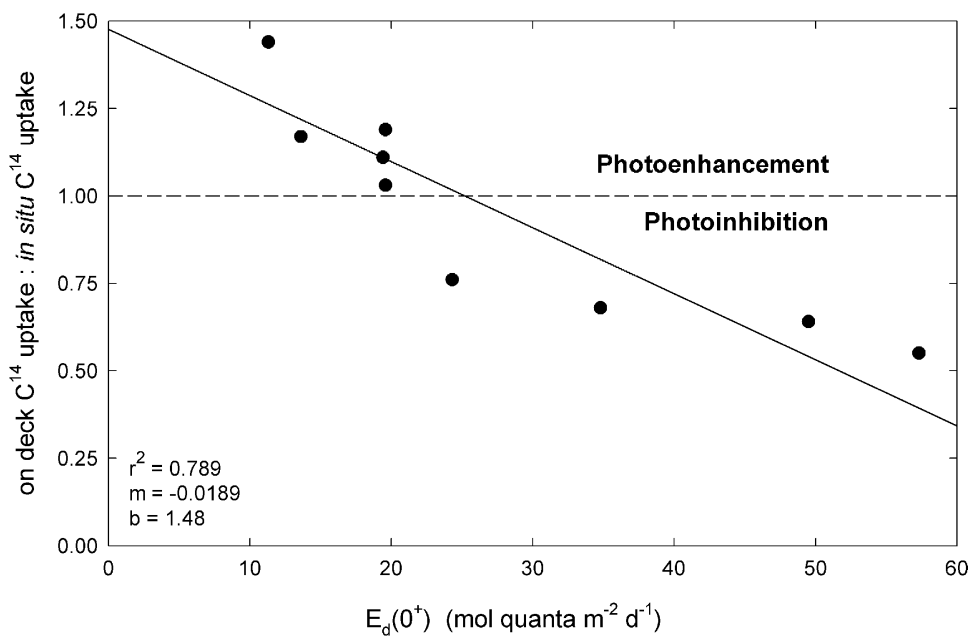

Fig. 3. Comparison of on-deck and in situ 24-h carbon uptake vs. integrated irradiance (mol photons $\mathrm{m}^{-2} \mathrm{~d}^{-1}$ ). On-deck samples were incubated in a " $50 \%$ light level" incubator. In situ samples were incubated near the $50 \%$ irradiance level. The dashed line represents unity between on-deck and in situ carbon-uptake rates. Ratios greater than 1 imply artifactual on-deck photoenhancement; ratios less than 1 imply artifactual on-deck photoinhibition. On cloudy, low-irradiance days, the extra irradiance received by on-deck incubators enhanced primary productivity relative to the near-surface in situ incubations; on sunny, high-light days, the irradiance subsidy photoinhibited phytoplankton and reduced daily primary productivity relative to near-surface in situ incubations. The solid line is a Model II linear regression $\left(r^{2}=0.789, m=-0.0189, b=1.48\right)$.

acts as a flat or cosine collector of light (Morel, 1991). In a uniformly diffuse environment, a spherical scalar irradiance collector can receive four times the irradiance of a cosine collector because the surface area of a sphere is four times greater than the surface area of a circle (Ramus, 1985; Kirk, 1996). Low solar elevation, long atmospheric path lengths, and cloudy conditions make the Southern Ocean an environment with highly diffuse irradiance. In order to correctly ascertain the light level of an on-deck incubator full of water, irradiance inside the incubator must be measured with a spherical or scalar PAR sensor because phytoplankton absorb irradiance from all directions. In contrast, irradiance outside the incubator must be measured with a flat, cosinecollector PAR sensor because the ocean receives radiant flux equal to only that measured on a horizontal surface just above the water, $E_{\mathrm{d}}\left(0^{+}\right)$ (Morel, 1991; Sakshaug et al., 1997).

\subsection{Photosynthetic performance}

Three measures of photosynthetic performance $\left(P_{\mathrm{opt}}^{\mathrm{B}}, P_{\max }^{\mathrm{B}}\right.$, and $\left.F_{\mathrm{v}} / F_{\mathrm{m}}\right)$ were used. $P_{\mathrm{opt}}^{\mathrm{B}}(\mathrm{mmol}$
$\mathrm{C} \mathrm{mg} \mathrm{Chl}^{-1} \mathrm{~d}^{-1}$ ) is the highest chlorophyll-normalized productivity rate in a $24-\mathrm{h}$ in situ or on-deck primary productivity incubation. For example, in a water column with uniform chlorophyll distribution, $P_{\mathrm{opt}}^{\mathrm{B}}$ will be at the depth with the highest productivity rate (usually near the surface). $P_{\max }^{\mathrm{B}}$, on the other hand, is the maximal, chlorophyllnormalized productivity rate in a 2 -h lightsaturated photosynthesis vs. irradiance ( $P$ vs. $E$ ) incubation at a single depth in the euphotic zone.

We used the $P_{\text {max }}^{\mathrm{B}}\left(\mathrm{mg} \mathrm{Cmg} \mathrm{Chl} \mathrm{C}^{-1} \mathrm{~h}^{-1}\right)$ rate of $P$ vs. $E$ incubations as a measure of photosynthetic performance during the January cruise, because neither in situ nor on-deck primary productivity rates were measured. $P$ vs. $E$ samples were incubated for $2 \mathrm{~h}$ in a temperature-controlled blue-light photosynthetron (Lewis and Smith, 1983; Lindley et al., 1995). $P_{\max }^{\mathrm{B}}$ values were calculated with the exponential photoinhibition model of Platt et al. (1980). $P_{\max }^{\mathrm{B}}$ is operationally distinct from $P_{\mathrm{opt}}^{\mathrm{B}}$ because $P_{\text {max }}^{\mathrm{B}}$ is measured in the lab with constant artificial irradiance for $2 \mathrm{~h}$, whereas $P_{\mathrm{opt}}^{\mathrm{B}}$ is measured in the field with ambient irradiance that can vary from light-limiting to photoinhibiting over the 24-h incubation 
(Behrenfeld and Falkowski, 1997). Despite these differences, $P_{\mathrm{opt}}^{\mathrm{B}}$ and $P_{\max }^{\mathrm{B}}$ are both measures of photosynthetic performance and we use them interchangeably.

The third measure of photosynthetic performance is $F_{\mathrm{v}} / F_{\mathrm{m}}$ (Kolber et al., 1994, 1998), a measure of the quantum efficiency of photosystem II (PSII). $F_{\mathrm{v}} / F_{\mathrm{m}}$ was measured with an in situ fast repetition rate fluorometer (FastTracka, Chelsea Instruments Ltd.) deployed on the CTD/rosette frame, and a pump-during-probe flow cytometer (Olson et al., 2000; Sosik and Olson, 2002). The measurements are based on the concept that when dark-adapted phytoplankton are illuminated, all of the functional reaction centers of PSII are open and the fluorescence is low $\left(F_{\mathrm{o}}\right)$; when a given reaction center has been excited, it is closed and its fluorescence increases; and when all the reaction centers are closed, fluorescence is maximal $\left(F_{\mathrm{m}}\right)$. Variable fluorescence $\left(F_{\mathrm{v}}=F_{\mathrm{m}}-F_{\mathrm{o}}\right)$, when normalized $\left(F_{\mathrm{v}} / F_{\mathrm{m}}\right)$, determines the proportion of functional PSII reaction centers.

\section{Results}

\subsection{Temporal variations}

Primary productivity increased rapidly in spring, peaked in summer, and decreased rapidly in fall, following the seasonal pattern of irradiance (Fig. 4A). At the end of October, primary productivity was $20 \mathrm{mmol} \mathrm{Cm}^{-2} \mathrm{~d}^{-1}$, and within 3 weeks doubled to $54 \mathrm{mmol} \mathrm{Cm}^{-2} \mathrm{~d}^{-1}$. During maximal irradiance (December), productivity was also maximal but variable in space, ranging between 33 and $93 \mathrm{mmol} \mathrm{Cm}^{-2} \mathrm{~d}^{-1}$. By midFebruary, primary productivity decreased to $31 \mathrm{mmol} \mathrm{C} \mathrm{m}^{-2} \mathrm{~d}^{-1}$ and then continued to decrease (Fig. 4A, Table 1).

The seasonal pattern of HPLC-derived chlorophyll concentration resembled the seasonal pattern of primary productivity, albeit with significantly greater range between seasonal maxima and minima. Productivity varied from 13 to $93 \mathrm{mmol} \mathrm{C} \mathrm{m}^{-2} \mathrm{~d}^{-1}$, whereas chlorophyll varied from 0.03 to $1.5 \mathrm{mg} \mathrm{Chl} \mathrm{m}^{-3}$ (Fig. 4B). In early spring chlorophyll values were less than $0.5 \mathrm{mg}$
$\mathrm{Chl} \mathrm{m}^{-3}$, but during late spring and early summer, maximal phytoplankton biomass tripled and ranged between 0.15 and $1.5 \mathrm{mg} \mathrm{Chl} \mathrm{m}{ }^{-3}$. In late summer, concentrations were consistently low $\left(<0.3 \mathrm{mg} \mathrm{Chl} \mathrm{m}^{-3}\right)$.

The timing of the seasonal increase in primary productivity and biomass supports the widespread consensus that the onset of primary productivity and biomass is regulated by irradiance and $Z_{\text {mix }}$ (Sverdrup, 1953; Smith and Nelson, 1985; Nelson and Smith, 1991). By the early spring cruise in late October and early November, $Z_{\mathrm{Cr}}$ was greater than $Z_{\text {mix }}$ (Table 1). Correspondingly, primary productivity and chlorophyll had begun to increase and were already elevated in comparison to the late summer values (Figs. 4 and 5). One month later (December), $Z_{\text {mix }}$ shoaled to less than onefifth of $Z_{\mathrm{Cr}}$, and primary productivity and chlorophyll doubled (Table 1).

\subsection{Spatial variations}

While the overall primary productivity and chlorophyll biomass covaried strongly with the temporal pattern of irradiance, there was also a spatial pattern of variability in the various hydrographic zones and in relation to the position of the $\Delta \mathrm{Si}_{\max }$ (Fig. 1). $\Delta \mathrm{Si}_{\max }$ is the position where change in silicic acid concentration divided by change in latitude is maximal. $\Delta \mathrm{Si}_{\max }$ propagated poleward between early spring and early summer and remained near the Southern Boundary of the ACC through early and late summer (Fig. 1).

During early spring (October-November) the productivity north of $\Delta \mathrm{Si}_{\max }$ was nearly double that of the region south of $\Delta \mathrm{Si}_{\max }(37 \pm 6$ vs.

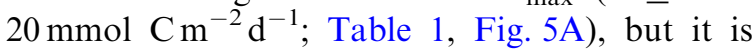
necessary to point out that there were many fewer observations south of $\Delta \mathrm{Si}_{\max }$. In contrast, chlorophyll did not have a meridional pattern across $\Delta \mathrm{Si}_{\text {max }}$ during early spring $(0.31 \pm 0.05$ vs. $0.37 \mathrm{mg}$ Chl m${ }^{-3}$; Table 1, Fig. 5B). In late spring (December), stations in the southern zones had slightly higher productivity than those to the north. To the south, the two stations nearest $\Delta \mathrm{Si}_{\max }$ had the two highest productivity rates observed (93 and $83 \mathrm{mmol} \mathrm{C} \mathrm{m}^{-2} \mathrm{~d}^{-1}$, Fig. 5A). To the north, mean primary productivity rates in the Subantarctic 
Date (1997 and 1998)

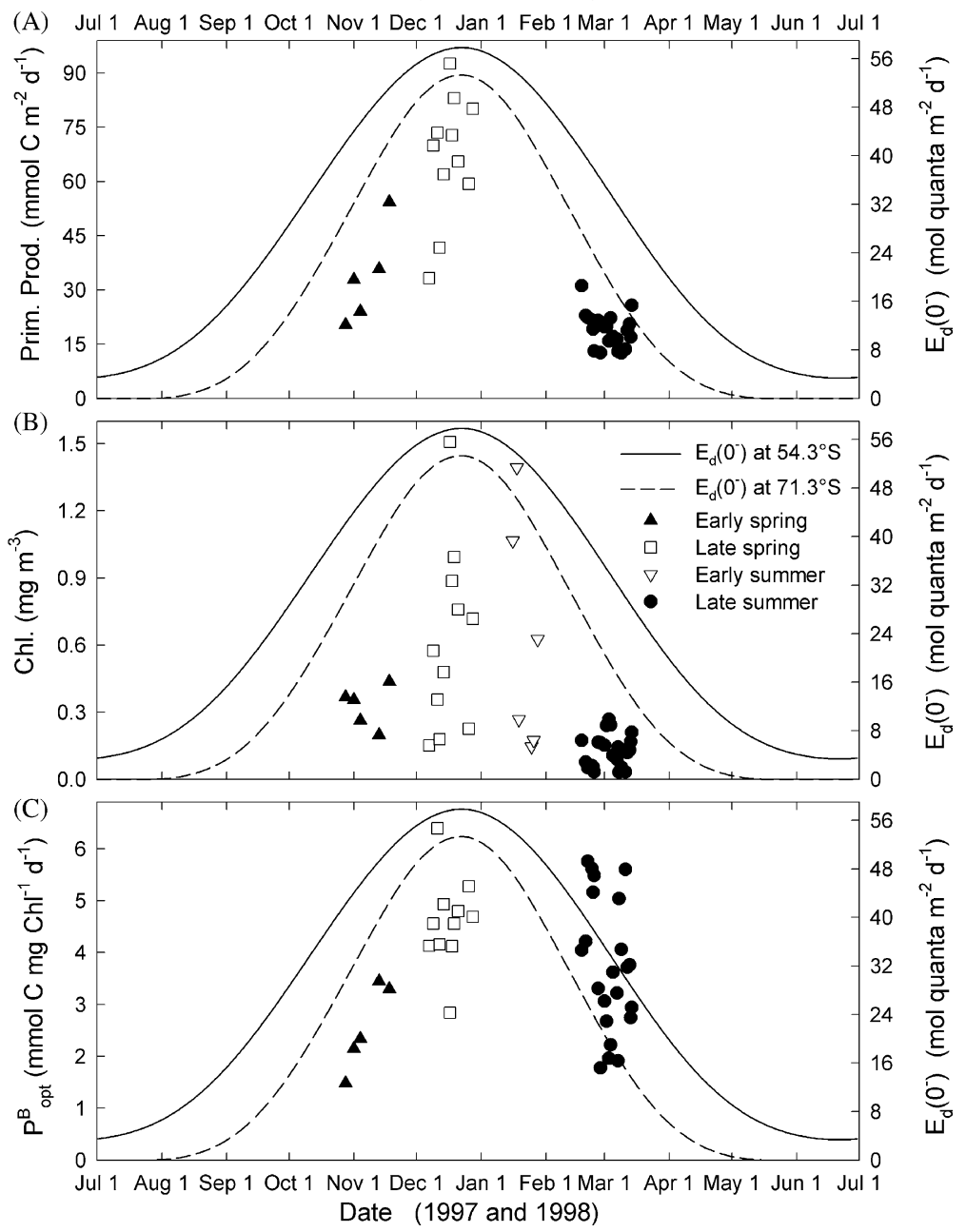

Fig. 4. Downwelling irradiance just below the surface of the ocean, $E_{\mathrm{d}}\left(0^{-}\right)$, and (A) primary productivity, (B) HPLC-derived chlorophyll at the depth of $P_{\mathrm{opt}}^{\mathrm{B}}$, and (C) $P_{\mathrm{opt}}^{\mathrm{B}}$ along the $170^{\circ} \mathrm{W}$ meridian from $54.3^{\circ} \mathrm{S}$ to $71.3^{\circ} \mathrm{S}$. The solid and dashed curves represent $E_{\mathrm{d}}\left(0^{-}\right)$at $54.3^{\circ} \mathrm{S}$ and $71.3^{\circ} \mathrm{S}$, respectively.

Zone and the APFZ were $58 \pm 14$ and

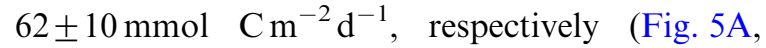
Table 1). Chlorophyll in late spring exhibited a greater meridional variability than in early spring. Highest chlorophyll concentrations (0.76$1.5 \mathrm{mg} \mathrm{Chl} \mathrm{m}^{-3}$ ) were near $\Delta \mathrm{Si}_{\text {max }}$; farther to the north, chlorophyll concentrations were lower (0.15-0.72 mg Chl m ${ }^{-3}$; Fig. 5B).

In early summer (January) high chlorophyll concentrations $\left(0.63\right.$ and $\left.1.4 \mathrm{mg} \mathrm{Chl} \mathrm{m}^{-3}\right)$ were also near $\Delta \mathrm{Si}_{\max }$, and to the north, concentrations were reduced ( $<0.3 \mathrm{mg} \mathrm{Chl} \mathrm{m}^{-3}$; Fig. 5B). By late summer (February-March), the three zones south of the APF had slightly lowered mean productivity rates $\left(17 \pm 1,18 \pm 4\right.$, and $\left.15 \pm 2 \mathrm{mmol} \mathrm{C}^{-2} \mathrm{~d}^{-1}\right)$ than did the zones north of the APF $(21 \pm 1$ and $25 \pm 4 \mathrm{mmol} \mathrm{C} \mathrm{m}^{-2} \mathrm{~d}^{-1}$; Table 1, Fig. 5A). In contrast, chlorophyll concentrations were highest in the northernmost and southernmost zones (Subantarctic Zone, $0.18 \pm 0.01 \mathrm{mg} \mathrm{Chl} \mathrm{m}^{-3}$; Subpolar Regime, $0.18 \pm 0.02 \mathrm{mg} \mathrm{Chl} \mathrm{m}{ }^{-3}$ ), whereas the APFZ, the Antarctic Zone, and the Southern 
Table 1

Means and standard error of properties within the zones and during the cruises depicted in Fig. 1

\begin{tabular}{|c|c|c|c|c|c|c|c|c|c|}
\hline Cruise & Region & $\begin{array}{l}\text { Primary } \\
\text { productivity } \\
\text { (mmol } \\
\mathrm{Cm}^{-2} \mathrm{~d}^{-1} \text { ) }\end{array}$ & 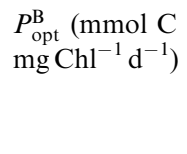 & Chl. $\left(\mathrm{mg} \mathrm{m}^{-3}\right)$ & Temp. $\left({ }^{\circ} \mathrm{C}\right)$ & $\mathrm{Si}(\mathrm{OH})_{4}(\mu \mathrm{M})$ & $\mathrm{NO}_{3}(\mu \mathrm{M})$ & $\begin{array}{l}Z_{\text {mix }}(\mathrm{m}) \Delta \sigma_{\mathrm{t}} \\
(0.01)\end{array}$ & $\begin{array}{l}\text { Critical depth } \\
\text { (m) }\end{array}$ \\
\hline \multirow{5}{*}{$\begin{array}{l}\text { Early spring } \\
\text { Oct-Nov } 1997\end{array}$} & Cruise mean & $33 \pm 6(5)$ & $2.5 \pm 0.4$ & $0.32 \pm 0.04$ & $0.4 \pm 0.7$ & $27 \pm 5$ & $28 \pm 1$ & $129 \pm 21$ & $183 \pm 21$ \\
\hline & North of $\Delta \mathrm{Si}_{\max }$ & $37 \pm 6(4)$ & $2.8 \pm 0.3$ & $0.31 \pm 0.05$ & $0.9 \pm 0.7$ & $23 \pm 3$ & $28 \pm 1$ & $145 \pm 17$ & $189 \pm 26$ \\
\hline & South of $\Delta \mathrm{Si}_{\max }$ & $20(1)$ & 1.5 & 0.37 & -1.7 & 46 & 30 & 67 & 159 \\
\hline & $\mathrm{APFZ}^{\mathrm{a}}$ & $37 \pm 6(4)$ & $2.8 \pm 0.3$ & $0.31 \pm 0.05$ & $0.9 \pm 0.7$ & $23 \pm 3$ & $28 \pm 1$ & $145 \pm 17$ & $189 \pm 26$ \\
\hline & Antarctic Zone & $20(1)$ & 1.5 & 0.37 & -1.7 & 46 & 30 & 67 & 159 \\
\hline \multirow{7}{*}{$\begin{array}{l}\text { Late spring } \\
\text { Dec } 1997\end{array}$} & Cruise mean & $67 \pm 5(11)$ & $4.6 \pm 0.3$ & $0.62 \pm 0.12$ & $2.1 \pm 0.9$ & $21 \pm 6$ & $23 \pm 1$ & $26 \pm 4$ & $166 \pm 26$ \\
\hline & North of $\Delta \mathrm{Si}_{\max }$ & $63 \pm 6(9)$ & $4.8 \pm 0.2$ & $0.49 \pm 0.10$ & $2.9 \pm 0.9$ & $13 \pm 3$ & $22 \pm 1$ & $29 \pm 4$ & $180 \pm 31$ \\
\hline & South of $\Delta \mathrm{Si}_{\max }$ & $83 \pm 10(2)$ & $3.5 \pm 0.6$ & $1.20 \pm 0.31$ & $-1.4 \pm 0.2$ & $57 \pm 5$ & $28 \pm 1$ & $12 \pm 1$ & $106 \pm 4$ \\
\hline & Subantarctic Zone & $58 \pm 14(3)$ & $4.7 \pm 0.3$ & $0.37 \pm 0.18$ & $6.0 \pm 0.6$ & $5.7 \pm 2.1$ & $20 \pm 2$ & $42 \pm 5$ & $235 \pm 84$ \\
\hline & APFZ & $62 \pm 10$ & $5.0 \pm 0.7$ & $0.52 \pm 0.04$ & $2.3 \pm 1.1$ & $9.9 \pm 2.6$ & $23 \pm 1$ & $19 \pm 1$ & $169 \pm 28$ \\
\hline & Antarctic Zone & $70 \pm 7(3)$ & $4.8 \pm 0.1$ & $0.74 \pm 0.15$ & $0.4 \pm 0.1$ & $24 \pm 6$ & $23 \pm 1$ & $26 \pm 6$ & $135 \pm 30$ \\
\hline & Southern $\mathrm{ACC}^{\mathrm{b}}$ Zone & $83 \pm 10(2)$ & $3.5 \pm 0.6$ & $1.20 \pm 0.31$ & $-1.4 \pm 0.2$ & $57 \pm 5$ & $28 \pm 1$ & $12 \pm 1$ & $106 \pm 4$ \\
\hline \multirow{10}{*}{$\begin{array}{l}\text { Late summer } \\
\text { Feb-Mar } 1998\end{array}$} & Cruise mean & $19 \pm 1(22)$ & $3.7 \pm 0.3$ & $0.13 \pm 0.02$ & $2.5 \pm 0.5$ & $26 \pm 5$ & $23 \pm 1$ & $49 \pm 4$ & $142 \pm 13$ \\
\hline & $\begin{array}{l}\text { Southward transect } \\
\text { (Feb 18-Mar 4) }\end{array}$ & $20 \pm 1(12)$ & $3.8 \pm 0.4$ & $0.14 \pm 0.02$ & $2.0 \pm 0.7$ & $28 \pm 7$ & $22 \pm 1$ & $48 \pm 6$ & $146 \pm 19$ \\
\hline & $\begin{array}{l}\text { Northward transect } \\
\text { (Mar 5-14) }\end{array}$ & $17 \pm 1(10)$ & $3.7 \pm 0.3$ & $0.11 \pm 0.02$ & $3.1 \pm 0.9$ & $24 \pm 8$ & $23 \pm 1$ & $50 \pm 7$ & $137 \pm 20$ \\
\hline & North of $\Delta \mathrm{Si}_{\max }$ & $20 \pm 1(14)$ & $4.4 \pm 0.3$ & $0.10 \pm 0.02$ & $4.0 \pm 0.5$ & $9.2 \pm 1.6$ & $23 \pm 1$ & $57 \pm 5$ & $159 \pm 17$ \\
\hline & South of $\Delta \mathrm{Si}_{\max }$ & $17 \pm 1(8)$ & $2.6 \pm 0.2$ & $0.18 \pm 0.02$ & $0.0 \pm 0.2$ & $55 \pm 1$ & $23 \pm 1$ & $34 \pm 5$ & $113 \pm 18$ \\
\hline & Subantarctic Zone & $25 \pm 4(3)$ & $3.2 \pm 0.4$ & $0.18 \pm 0.01$ & $7.2 \pm 0.4$ & $2.5 \pm 0.3$ & $19 \pm 1$ & $51 \pm 10$ & $67 \pm 11$ \\
\hline & APFZ & $21 \pm 1(5)$ & $4.6 \pm 0.4$ & $0.09 \pm 0.02$ & $4.2 \pm 0.3$ & $6.5 \pm 0.5$ & $24 \pm 1$ & $74 \pm 6$ & $163 \pm 26$ \\
\hline & Antarctic Zone & $15 \pm 2(4)$ & $5.1 \pm 0.4$ & $0.04 \pm 0.01$ & $2.4 \pm 0.1$ & $12 \pm 2$ & $24 \pm 1$ & $54 \pm 6$ & $208 \pm 14$ \\
\hline & Southern ACC Zone & $18 \pm 4(2)$ & $4.2 \pm 0.9$ & $0.10 \pm 0.07$ & $1.8 \pm 0.0$ & $20 \pm 1$ & $24 \pm 1$ & $33 \pm 13$ & $185 \pm 20$ \\
\hline & Subpolar Regime & $17 \pm 1(8)$ & $2.6 \pm 0.2$ & $0.18 \pm 0.02$ & $0.0 \pm 0.2$ & $55 \pm 1$ & $23 \pm 1$ & $34 \pm 5$ & $113 \pm 18$ \\
\hline
\end{tabular}

a APFZ: Antarctic Polar Front Zone.

b ACC: Antarctic Circumpolar Current.

Primary productivity is integrated to the $0.1 \%$ light level. Number of stations is in parentheses. $P_{\mathrm{opt}}^{\mathrm{B}}$ is the highest chlorophyll-normalized productivity rate. Chl. is the HPLC-derived total chlorophyll $a$ at the depth of $P_{\mathrm{opt}}^{\mathrm{B}}$. Temperature, silicic acid, and nitrate measurements are from $25 \mathrm{~m}$ and $Z_{\mathrm{mix}}$ is the mixed layer depth. Critical depth

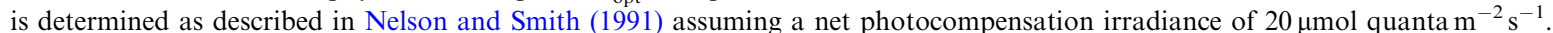



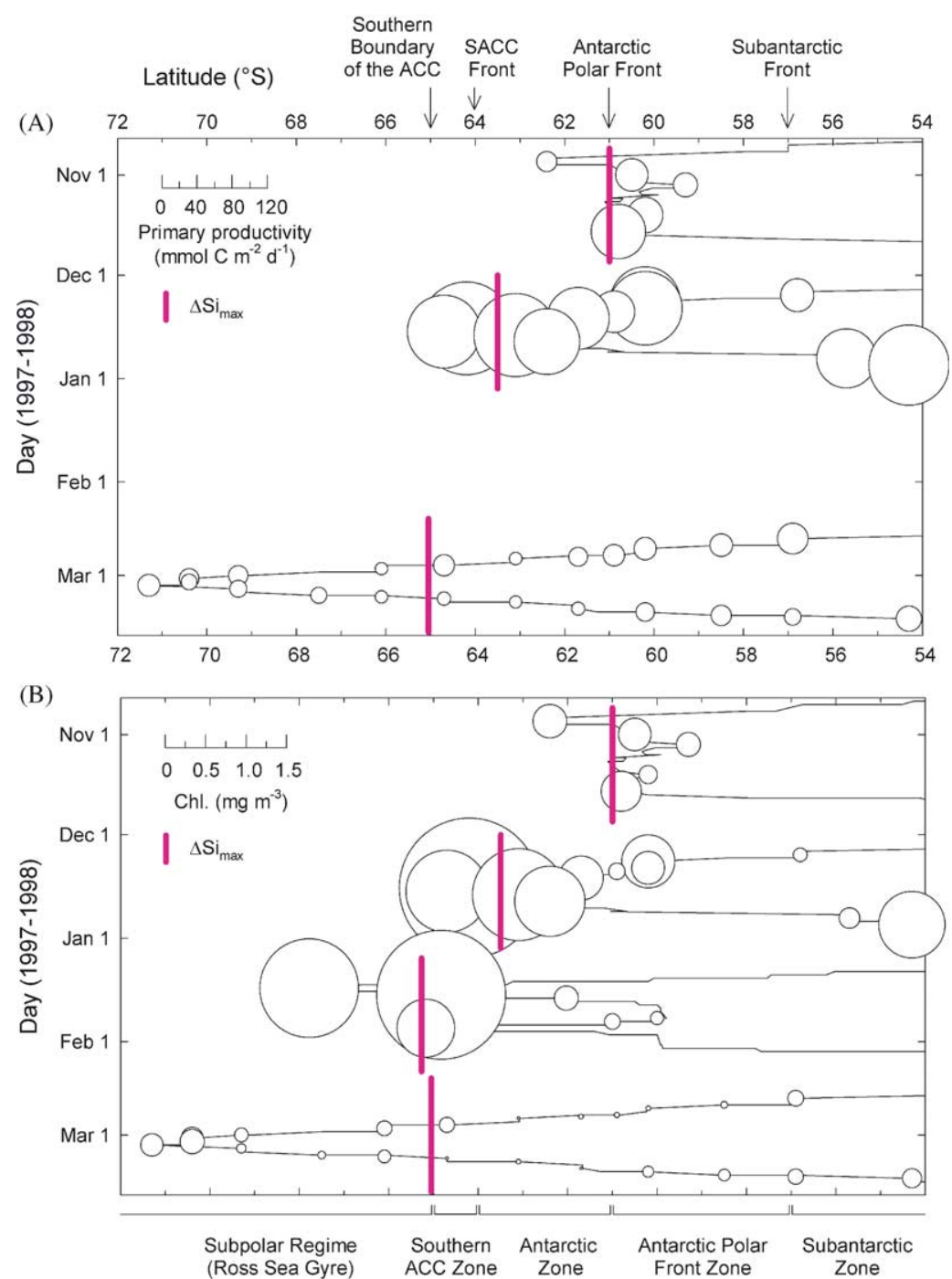

Fig. 5. Temporal and spatial distributions of (A) primary productivity and (B) HPLC-derived chlorophyll along $170^{\circ} \mathrm{W}$ in 1997 and 1998. The position of $\Delta \mathrm{Si}_{\max }$ is marked by vertical red lines. The diameter of the circles symbolizes the magnitude of primary productivity and chlorophyll.

ACC Zone had mean concentrations of $0.09 \pm 0.02, \quad 0.04 \pm 0.01, \quad$ and $\quad 0.10 \pm 0.07 \mathrm{mg}$ Chl $\mathrm{m}^{-3}$, respectively (Table 1 , Fig. 5B).

\subsection{Spatial pattern of $\Delta S i_{\max }$ and photosynthetic performance}

Unlike primary productivity and chlorophyll, $P_{\mathrm{opt}}^{\mathrm{B}}$ did not parallel irradiance through time (Fig. 4C). Instead, mean $P_{\mathrm{opt}}^{\mathrm{B}}$ had a meridional variation that was inversely proportional to the mean silicic acid concentration (Fig. 6A). To the south, mean silicic acid concentrations were high $(>50 \mu \mathrm{M})$ and mean $P_{\mathrm{opt}}^{\mathrm{B}}$ values were low $\left(\leqslant 2.7 \mathrm{mmol} \mathrm{C} \mathrm{mg} \mathrm{Chl}{ }^{-1} \mathrm{~d}^{-1}\right)$. To the north, however, silicic acid concentrations dropped to values as low as $2 \mu \mathrm{M}$, while $P_{\mathrm{opt}}^{\mathrm{B}}$ increased by $50 \%$ ( $\geqslant 4 \mathrm{mmol} \mathrm{C} \mathrm{mg} \mathrm{Chl}^{-1} \mathrm{~d}^{-1}$ ). This large northward decrease in silicic acid concentration and increase in $P_{\mathrm{opt}}^{\mathrm{B}}$ was not accompanied by reductions in 

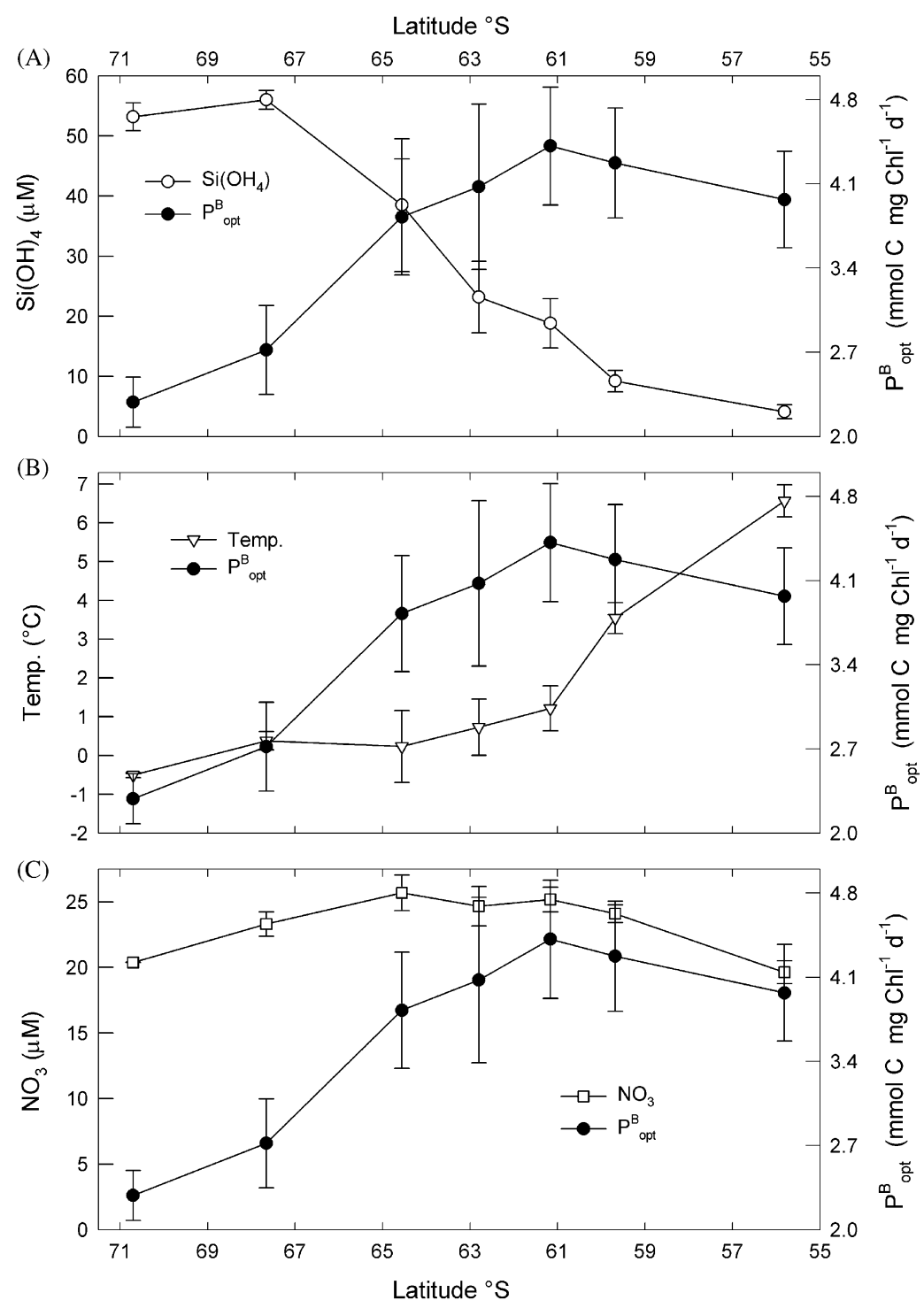

Fig. 6. $P_{\mathrm{opt}}^{\mathrm{B}}$ and near-surface (A) silicic acid, (B) temperature, and (C) nitrate vs. latitude. Points are binned averages and standard error of the 38 stations occupied.

nitrate concentrations (Fig. 6C). While water temperature did increase from south to north, the temperature increase occurred equatorward of the $P_{\mathrm{opt}}^{\mathrm{B}}$ increase; furthermore, temperatures continued to rise along the meridional transect as $P_{\mathrm{opt}}^{\mathrm{B}}$ reached a plateau (Fig. 6B).

These relationships between photosynthetic performance, silicic acid, temperature, and nitrate were consistent during the four JGOFS cruises.
During early spring, the ice edge was near $63^{\circ} \mathrm{S}$ and $\Delta \mathrm{Si}_{\max }$ coincided with the APF (Fig. 7). Stations north of $\Delta \mathrm{Si}_{\max }$ had a mean $P_{\mathrm{opt}}^{\mathrm{B}}$ of $2.8 \mathrm{mmol} \mathrm{C} \mathrm{mg} \mathrm{Chl}{ }^{-1} \mathrm{~d}^{-1}$; south of $\Delta \mathrm{Si}_{\max }, P_{\text {opt }}^{\mathrm{B}}$ was lower $\left(1.5 \mathrm{mmol} \mathrm{Cmg} \mathrm{Chl}^{-1} \mathrm{~d}^{-1}\right.$; Table 1 , Fig. 7). In late spring the ice had retreated poleward to $65^{\circ} \mathrm{S}$ and $\Delta \mathrm{Si}_{\text {max }}$ was located near $64^{\circ} \mathrm{S}$ (Fig. 8). As in early spring, the mean $P_{\mathrm{opt}}^{\mathrm{B}}$ of the stations south of $\Delta \mathrm{Si}_{\max }$ was slightly less than 


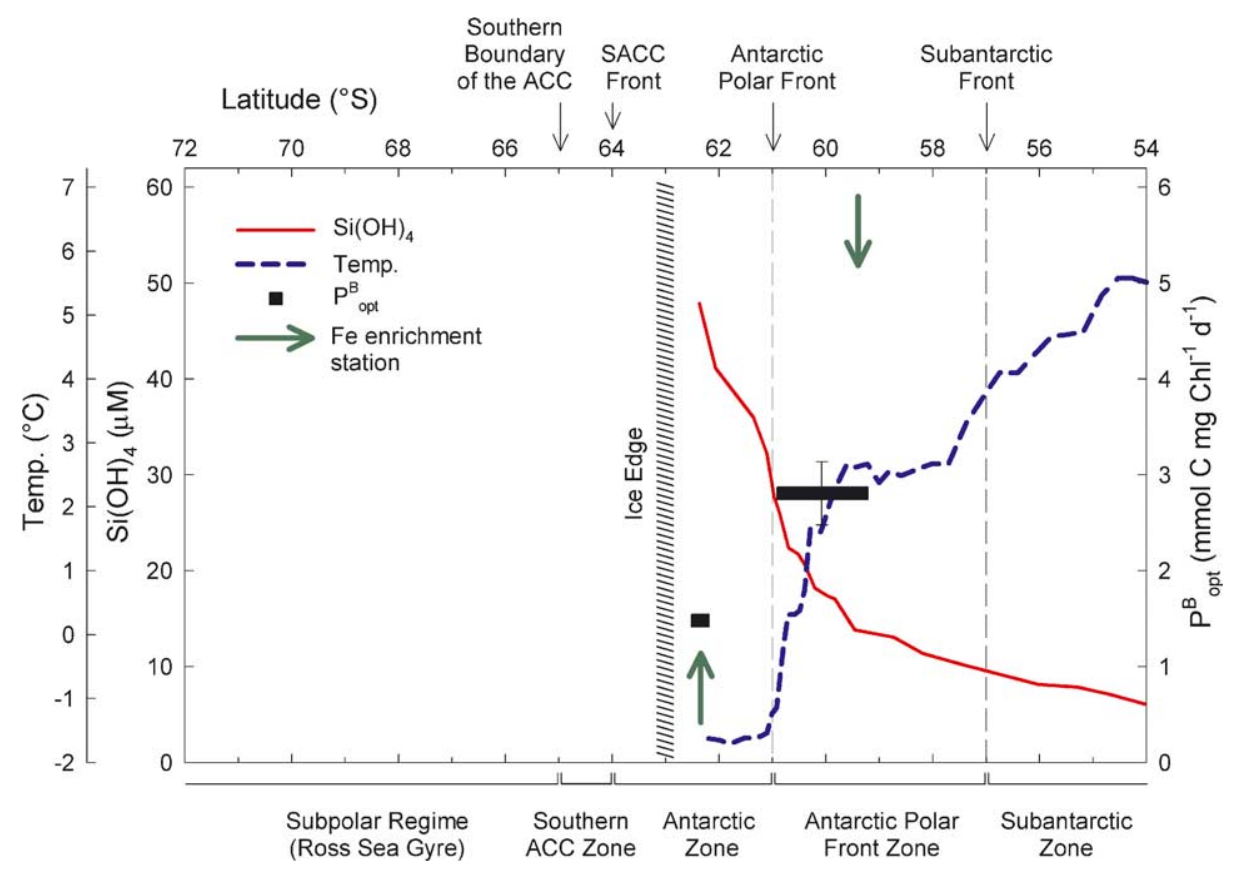

Fig. 7. Temperature, silicic acid, and $P_{\mathrm{opt}}^{\mathrm{B}}$ as a function of latitude for the austral early spring (October-November 1997) cruise. The solid red and dashed blue lines are latitudinally binned underway near-surface measurements of silicic acid and temperature, respectively. The black bar is a binned mean and standard error of $P_{\mathrm{opt}}^{\mathrm{B}}$ for the APFZ. The length of the black bar denotes the range over which data were available. The two green arrows indicate the stations where Franck et al. (2000) conducted on-deck ironenrichment experiments reporting a positive iron response south of $\Delta \mathrm{Si}_{\max }$ and no iron response north of $\Delta \mathrm{Si}_{\max }$.

the mean zonal values north of $\Delta \mathrm{Si}_{\text {max }}$ (Fig. 8). To the north of $\Delta \mathrm{Si}_{\max }$, the stations in the Antarctic Zone, the APFZ, and the Subantarctic Zone had average $P_{\mathrm{opt}}^{\mathrm{B}}$ values of $4.8 \pm 0.1,5.0 \pm 0.7$, and $4.7 \pm 0.3 \mathrm{mmol} \mathrm{C} \mathrm{mg} \mathrm{Chl}^{-1} \mathrm{~d}^{-1}$, respectively; those south of $\Delta \mathrm{Si}_{\max }$ averaged $3.5 \pm 0.6$ (Table 1 , Fig. 8).

The maximal chlorophyll-specific productivity $\left(P_{\max }^{\mathrm{B}}\right)$ in early summer had a spatial pattern similar to that of $P_{\mathrm{opt}}^{\mathrm{B}}$ in early and late spring (Fig. 9). $P_{\max }^{\mathrm{B}}\left(\mathrm{mg} \mathrm{Cmg} \mathrm{Chl}{ }^{-1} \mathrm{~h}^{-1}\right.$ ) is used during this time period as a measure of photosynthetic performance instead of $P_{\mathrm{opt}}^{\mathrm{B}} \quad$ (mmol $\mathrm{Cmg} \mathrm{Chl}^{-1} \mathrm{~d}^{-1}$ ) because $P_{\mathrm{opt}}^{\mathrm{B}}$ was not measured. North of $\Delta \mathrm{Si}_{\max }, P_{\max }^{\mathrm{B}}$ ranged between 3.8 and $5.2 \mathrm{mg} \mathrm{Cmg} \mathrm{Chl}{ }^{-1} \mathrm{~h}^{-1}$, while south of $\Delta \mathrm{Si}_{\text {max }}$, $P_{\max }^{\mathrm{B}}$ was considerably lower, ranging between 0.9 and $2.6 \mathrm{mg} \mathrm{C} \mathrm{mg} \mathrm{Chl}^{-1} \mathrm{~h}^{-1}$ (Fig. 9).

This pattern of photosynthetic performance was repeated again in February as the sea ice retreated to its seasonal minimum. Between February 18 and March $4, P_{\mathrm{opt}}^{\mathrm{B}}$ was lower south of $\Delta \mathrm{Si}_{\max }$ than it was north of $\Delta \mathrm{Si}_{\max }$ (Fig. 10B). The average $F_{\mathrm{v}} / F_{\mathrm{m}}$ value for $10-40 \mathrm{~m}$ was also higher in the northern low silicic acid waters, and lower in the southern high silicic acid waters (Sosik and Olson, 2002) (Fig. 10A). Similarly, dissolved iron concentrations were higher to the north of $\Delta \mathrm{Si}_{\max }$ and lower to the south (Fig. 11).

\section{Discussion}

\section{1. $\Delta \mathrm{Si}_{\max }$ and $\mathrm{Fe}$ in the regulation of photosynthetic performance}

Our results show that the most prominent relationship between photosynthetic performance and any environmental factor was a simple inverse relationship between $P_{\mathrm{opt}}^{\mathrm{B}}$ and silicic acid concentration (Fig. 6A). $P_{\mathrm{opt}}^{\mathrm{B}}$ was elevated in low silicic acid waters to the north of $\Delta \mathrm{Si}_{\max }$ and depressed in 


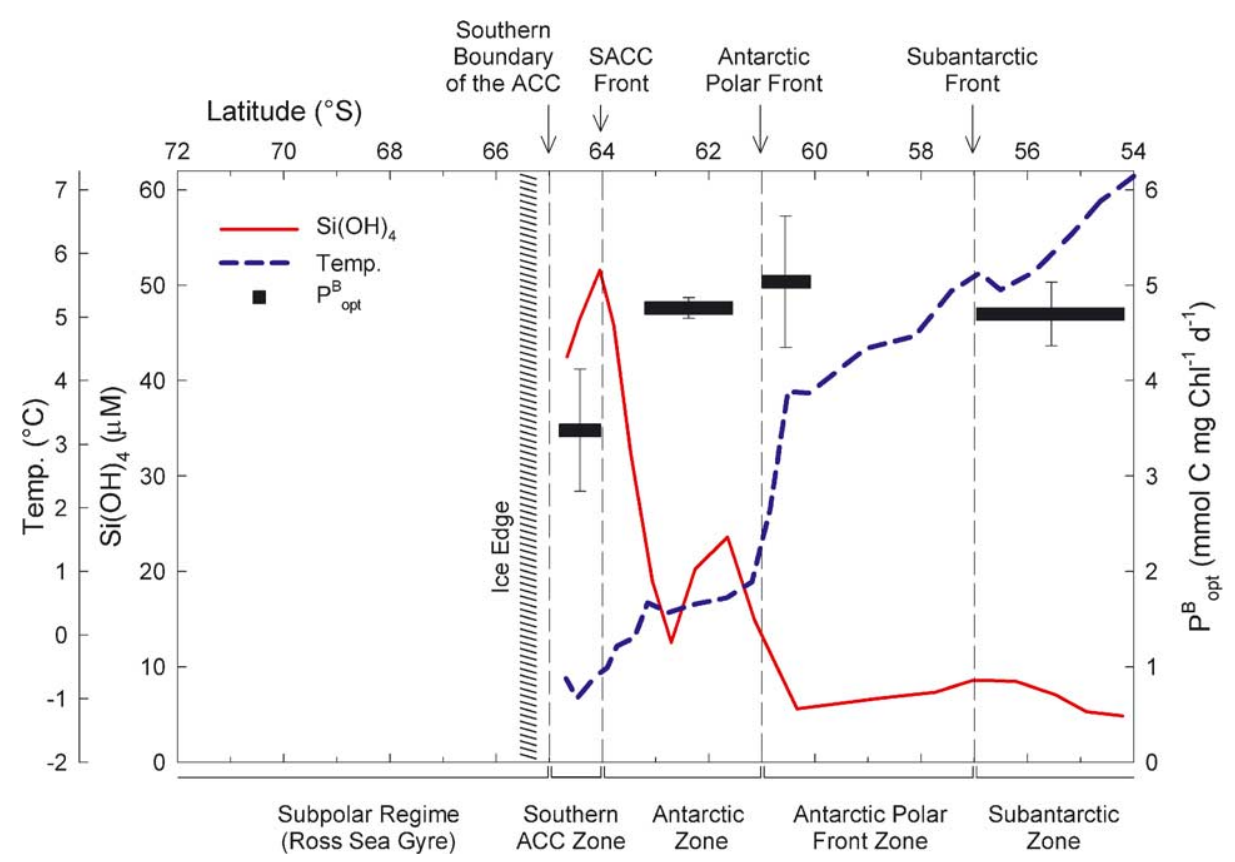

Fig. 8. Temperature, silicic acid, and $P_{\mathrm{opt}}^{\mathrm{B}}$ as a function of latitude for the late spring (December 1997) cruise. The solid red and dashed blue lines are latitudinally binned underway near-surface measurements of silicic acid and temperature, respectively. The black bars are binned means and standard error of $P_{\mathrm{opt}}^{\mathrm{B}}$ for each hydrographic zone. The length of the black bars denotes the range over which data were available.

high silicic acid waters to the south of $\Delta \mathrm{Si}_{\text {max }}$. This correlation persisted throughout the growing season, even as $\Delta \mathrm{Si}_{\max }$ traveled southward from $61^{\circ} \mathrm{S}$ to $65^{\circ} \mathrm{S}$ (Figs. $7-10$ ). We propose that this correlation between photosynthetic performance and silicic acid is best explained by iron regulation. Specifically, regions south of $\Delta \mathrm{Si}_{\max }$ have low photosynthetic performance because they are severely iron limited, whereas regions north of $\Delta \mathrm{Si}_{\text {max }}$ have high photosynthetic performance because they are iron sufficient.

Iron-enrichment experiments and ambient photosynthetic performance observations during early spring, early summer, and late summer provide corroborative evidence for these relationships among $\Delta \mathrm{Si}_{\max }$, photosynthetic performance, and iron regulation (Franck et al., 2000; Olson et al., 2000). In early spring (October-November), on-deck experiments demonstrated that iron enrichment had little effect on silicic acid uptake rates north of $\Delta \mathrm{Si}_{\text {max }}$ in the APFZ at $59.2^{\circ} \mathrm{S}$, indicating an iron sufficient environment (Franck et al., 2000). At the same time, we measured a relatively high ambient $P_{\mathrm{opt}}^{\mathrm{B}}$ of $2.3 \mathrm{mmol}$ $\mathrm{Cmg} \mathrm{Chl}^{-1} \mathrm{~d}^{-1}$ (Fig. 7) at this station. However, iron enrichment increased silicic acid uptake rates 3-5 times over controls south of $\Delta \mathrm{Si}_{\text {max }}$ at $62.3^{\circ} \mathrm{S}$ in the Antarctic Zone (Franck et al., 2000), where we measured a lower $P_{\mathrm{opt}}^{\mathrm{B}}$ of $1.5 \mathrm{mmol}$ $\mathrm{C} \mathrm{mg} \mathrm{Chl}^{-1} \mathrm{~d}^{-1}$ (Fig. 7).

In early summer (January), another set of ondeck iron enrichments (shifted south by several degrees) produced similar results. At $67.8^{\circ} \mathrm{S}$ in the Subpolar Regime, south of $\Delta \mathrm{Si}_{\max }$, Franck et al. (2000) found 3-5-fold increases in silicic acid uptake rates in response to iron addition, where we measured a low ambient $P_{\max }^{\mathrm{B}}$ of $0.9 \mathrm{mg}$ $\mathrm{Cmg} \mathrm{Chl}^{-1} \mathrm{~h}^{-1}$ (Fig. 9). To the north of $\Delta \mathrm{Si}_{\max }$ (Antarctic Zone, $62.0^{\circ} \mathrm{S}$ ), in waters that had responded positively to iron 2 months earlier, Franck et al. (2000) observed little response of silicic acid uptake rates to iron enrichments. We measured a relatively high ambient $P_{\max }^{\mathrm{B}}$ of $3.8 \mathrm{mg}$ $\mathrm{C} \mathrm{mg} \mathrm{Chl}^{-1} \mathrm{~h}^{-1}$ at this location (Fig. 9). 


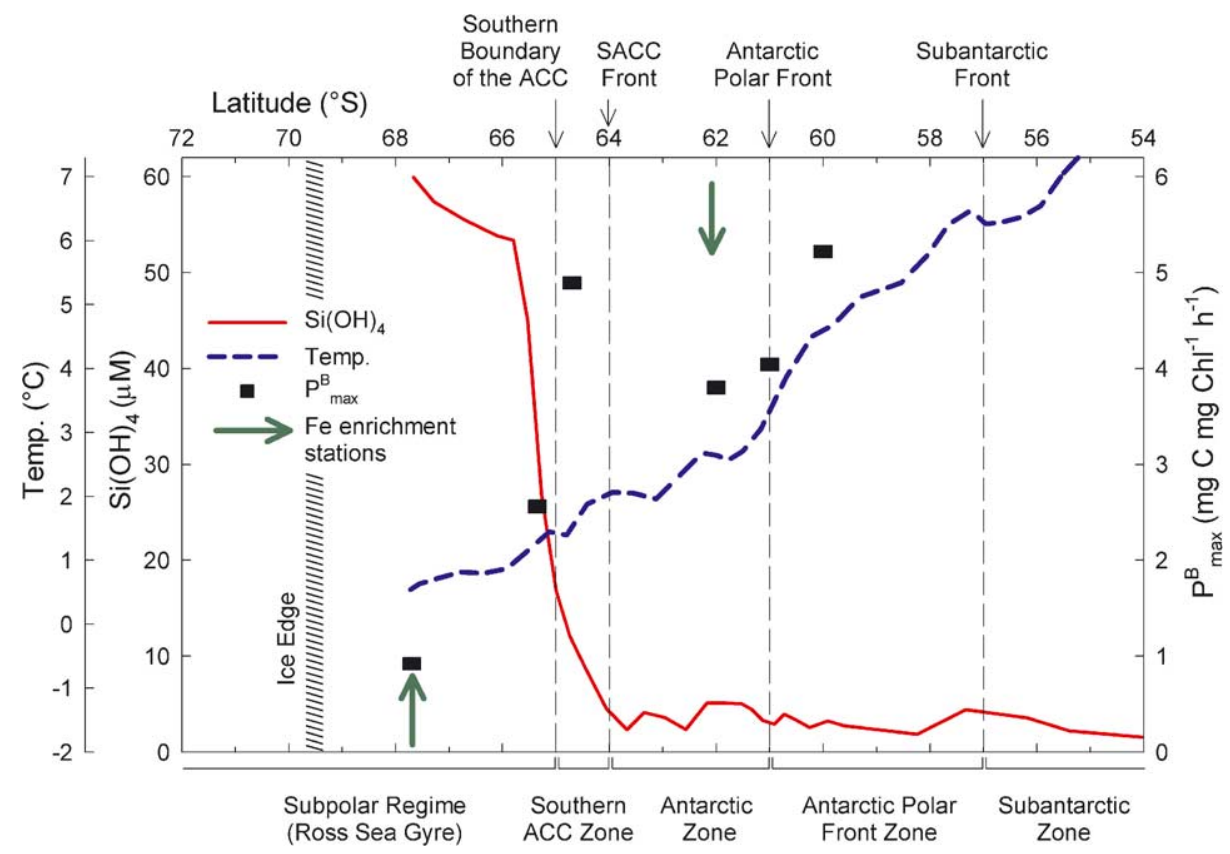

Fig. 9. Temperature, silicic acid, and $P_{\max }^{\mathrm{B}}$ as a function of latitude for the early summer (January 1998) cruise. The two green arrows indicate $P_{\max }^{\mathrm{B}}$ at stations where Franck et al. (2000) conducted on-deck iron-enrichment experiments, reporting a positive iron response south of $\Delta \mathrm{Si}_{\max }$ and no iron response north of $\Delta \mathrm{Si}_{\max }$. The solid red and dashed blue lines are latitudinally binned underway nearsurface measurements of silicic acid and temperature, respectively.

In late summer, Olson et al. (2000) also detected significant increases in $F_{\mathrm{v}} / F_{\mathrm{m}}$ in response to ondeck iron enrichment at locations south of $\Delta \mathrm{Si}_{\text {max }}$, but little or no response north of $\Delta \mathrm{Si}_{\max }$. To the south, the positive response to iron enrichment was accompanied by low ambient $F_{\mathrm{v}} / F_{\mathrm{m}}$, while to the north a lack of a response was accompanied by high ambient $F_{\mathrm{v}} / F_{\mathrm{m}}$. Our measure of photosynthetic performance from the same stations as the Olson et al. (2000) enrichments yielded similar results: to the south, where the index of response to iron enrichment was high, we measured low $P_{\mathrm{opt}}^{\mathrm{B}}$; conversely, to the north, where the index of response to iron enrichment was low, we measured high $P_{\mathrm{opt}}^{\mathrm{B}}$ (Fig. 12A). Correspondingly, the relationship between initial $P_{\mathrm{opt}}^{\mathrm{B}}$ and initial $F_{\mathrm{v}} / F_{\mathrm{m}}$ was strong: low initial $F_{\mathrm{v}} / F_{\mathrm{m}}$ measurements were paired with low $P_{\mathrm{opt}}^{\mathrm{B}}$ rates and high initial $F_{\mathrm{v}} / F_{\mathrm{m}}$ measurements were paired with high $P_{\mathrm{opt}}^{\mathrm{B}}$ rates (Fig. 12B).

Furthermore, direct measurements of $F_{\mathrm{v}} / F_{\mathrm{m}}$, $P_{\mathrm{opt}}^{\mathrm{B}}$, dissolved iron, and silicic acid demonstrated that $F_{\mathrm{v}} / F_{\mathrm{m}}, P_{\mathrm{opt}}^{\mathrm{B}}$, and iron were elevated where silicic acid concentrations were low (Fig. 10, 11 and $12 \mathrm{C})$. Conversely, surface $F_{\mathrm{v}} / F_{\mathrm{m}}, P_{\mathrm{opt}}^{\mathrm{B}}$, and iron concentrations were depressed where silicic acid concentrations were high (Fig. 10, 11 and 12C).

\section{2. $U C D W$ and the spatial regulation of photosynthetic performance}

The change in position of $\Delta \mathrm{Si}_{\max }$ through time defines three regions. One region was always north of $\Delta \mathrm{Si}_{\max }$ and had low silicic acid concentrations. A second region was south of $\Delta \mathrm{Si}_{\max }$ in spring and north of $\Delta \mathrm{Si}_{\text {max }}$ in summer; accordingly, it had high silicic acid concentrations in the spring and low silicic acid concentrations in the summer. A third region was always south of $\Delta \mathrm{Si}_{\text {max }}$ and had high silicic acid concentrations (Fig. 1). These regions are delimited by the APF and the Southern Boundary of the ACC and had distinct photosynthetic performances due to different iron 


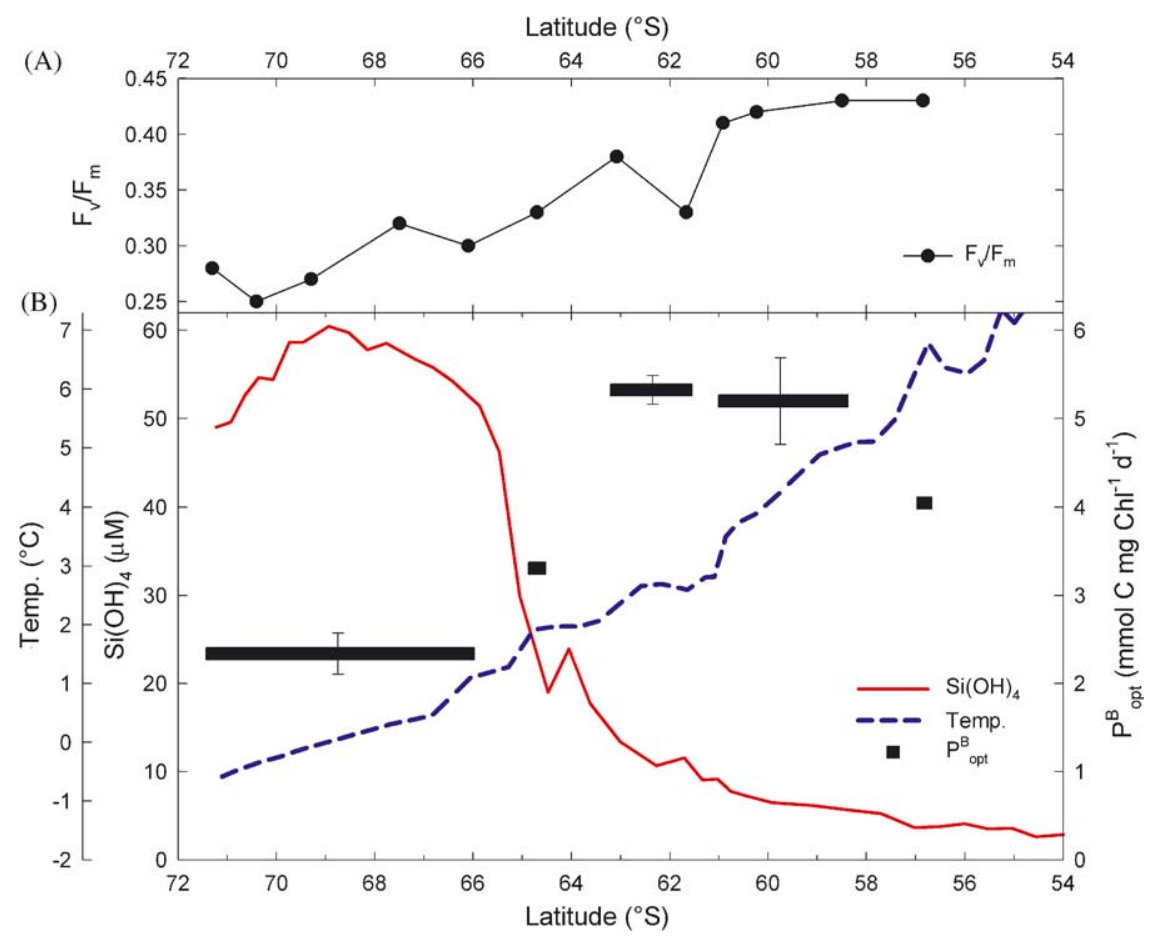

Fig. 10. Southward transect in late summer (February-March 1998) along $170^{\circ} \mathrm{W}$. (A) Mean $F_{\mathrm{v}} / F_{\mathrm{m}}$ values for $10-40 \mathrm{~m}$ from CTD casts vs. latitude (Sosik and Olson, 2002). (B) Temperature, silicic acid, and maximal chlorophyll-specific productivity, $P_{\mathrm{opt}}^{\mathrm{B}}$, vs. latitude. The solid red and dashed blue lines are latitudinally binned underway near-surface measurements of silicic acid and temperature for only the southward transect. The black bars are binned means and standard error of $P_{\text {opt }}^{\mathrm{B}}$ for each of the five zones designated in Figs. 1 and 2. The length of the black bars denotes the range over which data were available.

regulation characteristics. We argue that these differences in iron regulation characteristics are due to differences in phytoplankton cell size and UCDW upwelling in these regions.

Phytoplankton cell size is a key factor in iron regulation because smaller phytoplankton are better adapted to low iron levels than larger phytoplankton (Morel et al., 1991b; Sunda and Huntsman, 1995; Erdner and Anderson, 1999; Timmermans et al., 2001). UCDW is also important to iron regulation because direct measurements of iron concentration and observations of biomass abundance near UCDW upwelling sites indicate that UCDW is a significant source of iron for phytoplankton. Löscher et al. (1997) and Löscher (1999) measured elevated dissolved iron concentrations in UCDW in the APF region as compared to deep waters farther south. Pollard et al. (1995) reported that upwelling of UCDW produced a bloom $10 \mathrm{~km}$ wide with chlorophyll concentrations greater than $5 \mathrm{mg} \mathrm{Chl} \mathrm{m}{ }^{-3}$. Prézelin et al. (2000) also linked UCDW with high biomass diatom blooms, and Tynan (1998) coupled the circumpolar distribution of increased phytoplankton biomass, krill, and baleen whales with the "non-uniform high-latitude penetration of shoaled, nutrient-rich UCDW" (Tynan, 1998). This iron-rich upwelling UCDW is present in near-surface waters of the Southern ACC and Antarctic Zones, but absent in the near-surface waters of the Subpolar Regime, the APFZ, and the Subantarctic Zone (Figs. 2 and 11).

\subsubsection{North of the APF $\left(61^{\circ} \mathrm{S}\right)$ : the APFZ and Subantarctic Zone}

The region north of the APF was always north of $\Delta \mathrm{Si}_{\text {max }}$ and always had relatively low silicic acid concentrations (Fig. 1). The phytoplankton community here had consistently elevated photosynthetic performance and did not respond to iron 


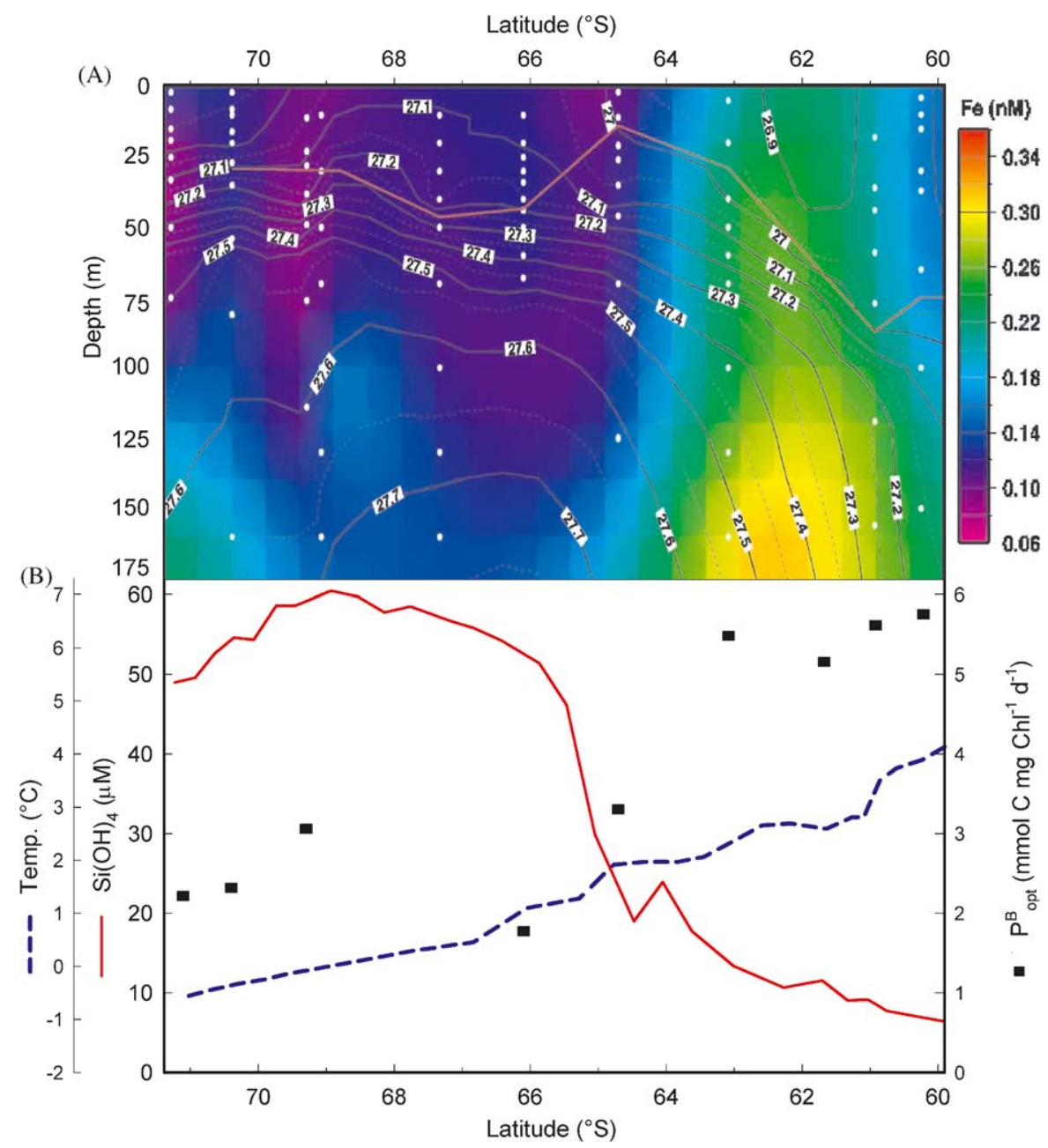

Fig. 11. Southward transect in late summer (February-March 1998) along $170^{\circ} \mathrm{W}$. (A) Contoured section of dissolved iron in surface waters. Potential density isopleths are represented by black contour lines. The bold red line marks the depth of the mixed layer at each station. Open circles show the locations of samples for dissolved iron. At the Southern Boundary of the ACC $\left(65^{\circ} \mathrm{S}\right)$, the shift from upwelling-dominated ACC waters to the horizontally stratified, clockwise surface circulation of the Subpolar Regime (Ross Sea Gyre) is demonstrated by the orientation of the density isopleths. The circumpolar circulation north of $65^{\circ} \mathrm{S}$ consists of vertical isopleths representing the UCDW upwelling with associated elevated iron, while south of $65^{\circ} \mathrm{S}$, the Ross Sea Gyre has horizontal isopleths representing a gyre circulation that is isolated from the upwelling UCDW. (B) $P_{\mathrm{opt}}^{\mathrm{B}}$ and latitudinally binned silicic acid vs. latitude for the same transect.

enrichment during the early spring (Franck et al., 2000). This can be explained by the dominance of smaller (nano- and pico-) phytoplankton (Brown and Landry, 2001a, b; Landry et al., 2001) and year-round irradiance and primary productivity (Moore and Abbott, 2000). The year-round available irradiance, ice-free conditions, and small cell size of this region create a "balanced" oceanic food web as defined by Landry et al. (1997). Phytoplankton productivity is balanced with zooplankton grazing, resulting in little seasonality in chlorophyll concentrations (Banse, 1996). The dominant small eucaryotic phytoplankton are well adapted to growth at low iron levels and are vulnerable to microzooplankton grazing that rapidly recycles iron (Morel et al., 1991b; Price 

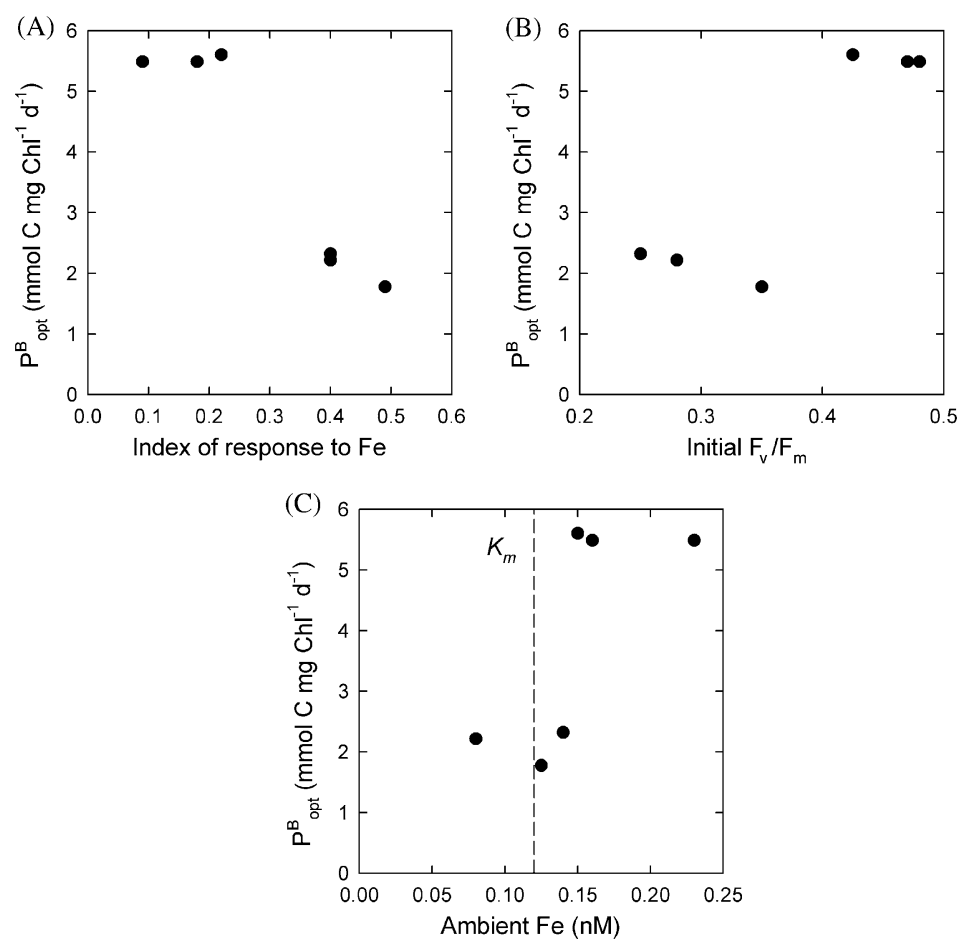

Fig. 12. Relationships between iron and photosynthetic performance properties for the late summer (February-March 1998) cruise. (A) $P_{\mathrm{opt}}^{\mathrm{B}}$ as a function of the relative response to the iron-enrichment experiments of Olson et al. (2000) for independent samples collected at the same station. The response to iron was quantified by comparing control and enriched $F_{\mathrm{v}} / F_{\mathrm{m}}$ values using the following index: $\left[\left(F_{\mathrm{v}} / F_{\mathrm{m}}\right)_{+\mathrm{Fe}}-\left(F_{\mathrm{v}} / F_{\mathrm{m}}\right)_{\text {control }}\right] /\left[0.65-\left(F_{\mathrm{v}} / F_{\mathrm{m}}\right)_{\text {control }}\right]$, where 0.65 represents the maximum potential value of $F_{\mathrm{v}} / F_{\mathrm{m}}$. (B) $P_{\mathrm{opt}}^{\mathrm{B}}$ as a function of variable fluorescence $\left(F_{\mathrm{v}} / F_{\mathrm{m}}\right)$ at the beginning of the Olson et al. (2000) iron-enrichment experiments for independent samples from the same station. (C) $P_{\mathrm{opt}}^{\mathrm{B}}$ as a function of ambient iron concentration (Measures and Vink, 2001). The dotted line marks the half-saturation constant $\left(K_{\mathrm{m}}\right)$ of iron, $0.12 \mathrm{nM}$ (Fitzwater et al., 1996). The three $P_{\mathrm{opt}}^{\mathrm{B}}$ measurements less than $3 \mathrm{mmol}$ $\mathrm{Cmg} \mathrm{Chl}^{-1} \mathrm{~d}^{-1}$ were made south of $\Delta \mathrm{Si}_{\max }$ and had an average silicic acid concentration of $52 \mu \mathrm{M}$. The three $P_{\text {opt }}^{\mathrm{B}}$ measurements greater than $5 \mathrm{mmol} \mathrm{C} \mathrm{mg} \mathrm{Chl} l^{-1} \mathrm{~d}^{-1}$ were made north of $\Delta \mathrm{Si}_{\max }$ and had an average silicic acid concentration of $15 \mu \mathrm{M}$.

et al., 1994; Longhurst, 1998). As a result, this region displayed little or no signs of iron limitation in the early spring (Franck et al., 2000), despite the absence of upwelling UCDW (Fig. 2).

\subsubsection{South of the APF and north of the Southern} Boundary of the $A C C\left(61-65^{\circ} \mathrm{S}\right)$ : The Antarctic Zone and the Southern ACC Zone

The second region, south of the APF and north of the Southern Boundary of the ACC $\left(61-65^{\circ} \mathrm{S}\right)$, is complex in that it was south of $\Delta \mathrm{Si}_{\max }$ in spring (high silicic acid concentrations) and north of $\Delta \mathrm{Si}_{\text {max }}$ in summer (low silicic acid concentrations) (Fig. 1). Photosynthetic performance switched from low to high as the season progressed and as $\Delta \mathrm{Si}_{\text {max }}$ traveled south. Likewise, the phytoplank- ton community switched from being regulated by iron in the spring to being iron replete in the summer. Although this shift from iron limitation to iron sufficiency may seem counterintuitive, it can be explained by the winter resupply of ironrich UCDW (Fig. 2) and a shift in phytoplankton community structure from larger phytoplankton $(>20 \mu \mathrm{m})$ in spring to smaller phytoplankton in summer (Brown and Landry, 2001a, b; Brzezinski et al., 2001).

During winter in this region, the ice cover and low incident irradiance effectively stopped primary productivity, but upwelling associated with the circumpolar current continued throughout the winter and replenished the surface layer with UCDW along $170^{\circ} \mathrm{W}$ (Figs. 2 and 11). The degree 
to which UCDW replenishes the surface layer between $61^{\circ} \mathrm{S}$ and $65^{\circ} \mathrm{S}$ - along $170^{\circ} \mathrm{W}$-is uncertain. However, Hoppema et al. (2000) demonstrated that, at the prime meridian, $90 \%$ of Antarctic surface water in the southern section of the ACC is comprised of UCDW (with the rest made up of northward-flowing surface water from the Subpolar Regime). The increase in silicic acid between early summer and late summer in the region between $61^{\circ} \mathrm{S}$ and $65^{\circ} \mathrm{S}$ is also a good indicator of the strength of UCDW replenishment (Figs. 1 and 2).

Thus, in spring, this region had high silicic acid concentrations, relatively high iron concentrations (Measures and Vink, 2001), and was south of $\Delta \mathrm{Si}_{\text {max }}$. As seasonal ice receded, irradiance increased, and the surface layer stabilized, larger autotrophs $(>20 \mu \mathrm{m})$ dominated this region (Brown and Landry, 2001a, b; Brzezinski et al., 2001). The larger autotrophs-particularly diatoms (Brzezinski et al., 2001)-took up the replenished macronutrients and iron, and accumulated biomass. The observed accumulation of phytoplankton biomass in this situation is typically attributed to a reduced zooplankton abundance (Evans and Parslow, 1985; Steele and Henderson, 1992). In this case, the reduced zooplankton abundance is likely a consequence of unfavorable food conditions, characteristic of the winter, under-ice period. Despite sufficient iron for the large diatoms to reduce silicic acid levels from 47 to $14 \mu \mathrm{M}$ in 54 days, these diatoms were regulated by iron: the diatoms had low photosynthetic performance (Fig. 7) and responded positively to iron enrichment (Franck et al., 2000).

Through a combination of drawdown and export of iron and silicic acid, the dominance of these large diatoms was limited to a short pulse of increased biomass that traveled south with $\Delta \mathrm{Si}_{\text {max }}$. By early summer, there was a prevalence of empty or nearly empty diatom frustules as smaller phytoplankton, well adapted to low iron levels (Morel et al., 1991a), dominated the region (Brown and Landry, 2001a). With this switch in community structure from micro- to nano- and picoplankton, the Antarctic and Southern ACC Zones switched from low to high photosynthetic performance (Figs. 7 and 9). These smaller phyto- plankton had higher ambient photosynthetic performance (Fig. 9), did not respond to ironenrichment experiments (Franck et al., 2000), and, thus, were iron sufficient.

By late summer, despite high photosynthetic performance and favorable irradiance and mixing regimes $\left(Z_{\text {mix }} / Z_{\mathrm{Cr}}=0.35\right)$, biomass concentrations and primary productivity rates in this region decreased and were at the lowest level that we measured on all four cruises (Table 1). High photosynthetic performance coupled with decreasing biomass and decreasing productivity is indicative of assemblages of small phytoplankton that are grazer regulated (Price et al., 1994; Banse, 1996). This region (the SIZ between the APF and the Southern Boundary of the ACC) appeared to shift to the kind of "grazer-controlled population" described by Price et al. (1994) and Banse (1996) with the exception that the composition of the phytoplankton community appears to be controlled by silicic acid, while photosynthetic performance was high and not iron-limited.

\subsubsection{South of the southern boundary of the ACC $\left(65^{\circ} \mathrm{S}\right)$ : The Subpolar Regime}

The third region, the Subpolar Regime north of the continental margin, was always south of $\Delta \mathrm{Si}_{\max }$ and always had relatively high silicic acid concentrations (Fig. 1). Three indicators-low $P_{\mathrm{opt}}^{\mathrm{B}}$, low $F_{\mathrm{v}} / F_{\mathrm{m}}$, and a positive response to iron enrichment - suggest that phytoplankton in this region were permanently iron deficient (Figs. 912). We argue that the iron deficiency within this region caused the abrupt halt of the diatom-driven $\Delta \mathrm{Si}_{\text {max }}$ at the northern boundary of this region (Fig. 1) and can be explained by the absence of UCDW (Figs. 2 and 11).

The Subpolar Regime is, by definition (Orsi et al., 1995), isolated from iron-rich UCDW upwelling (Figs. 2 and 11). Even though the Subpolar Regime has significant vertical mixing in the winter, the surface water never mixes with UCDW (Figs. 2 and 11). As a result, phytoplankton within the Subpolar Regime had low photosynthetic performance, responded positively to iron enrichment, and were persistently iron deficient (Figs. 9-12) (Franck et al., 2000; Olson et al., 2000). The diatom bloom and associated $\Delta \mathrm{Si}_{\max }$, 
which traversed the Antarctic and Southern ACC Zones, were strongly iron regulated (Figs. 7 and 8) (Franck et al., 2000), and thus, could not continue in the relatively iron-poor Subpolar Regime, south of the Southern Boundary of the ACC.

\subsection{Response to iron additions}

Our results suggest that the three Antarctic productivity regimes (presented in a different order than above) would respond differently to in situ iron additions as follows: (1) the region south of the Southern Boundary of the ACC would always respond positively to iron addition during the austral growing season; (2) the region north of the APF and north of the seasonal ice was found to be silicic acid limited and iron sufficient in early spring and would not develop a high biomass diatom bloom in response to added iron; and (3) the region between the APF and the Southern Boundary of the ACC - and within the Seasonal Ice Zone (SIZ) - will respond positively to iron enrichment in the spring, but not in the summer.

The region south of the Southern Boundary of the ACC, the Subpolar Regime, is permanently low in iron because it is south of and spatially isolated from the upwelled iron-rich UCDW (Figs. 2 and 11). Measurements of photosynthetic performance in this region were ubiquitously low, silicic acid concentrations were greater than $50 \mu \mathrm{M}$, and the phytoplankton assemblage responded positively to iron additions (Franck et al., 2000; Olson et al., 2000). Therefore, an intentional iron addition south of the Southern Boundary of the ACC would likely result in a relatively high biomass diatom bloom that would not be silicic acid limited. Of the three regions described, the Subpolar Regime, which surrounds the continent of Antarctica, is likely to show the largest response to naturally varying aeolian dust flux or intentional in situ iron addition.

North of the Polar Front, silicic acid concentrations appear to be limiting for diatom growth during early spring (Franck et al., 2000), but also during other periods of the growing season (Zentara and Kamykowski, 1981; Daly et al., 2001). Nano- and picoplankton rely on efficient iron recycling through grazing by microhetero- throphs and have high photosynthetic performance. It seems unlikely that an iron addition, without a parallel silicic acid addition, would result in the accumulation of significant levels of diatom biomass in this region.

In the Antarctic Zone and Southern ACC Zone, between the APF and Southern Boundary of the ACC, the response to iron addition will depend on the time of year. Along $170^{\circ} \mathrm{W}$, the retreat of the seasonal ice and the increased irradiance in spring set the stage for a diatom bloom dense enough to draw down the nutrients replenished from UCDW upwelling throughout the winter and early spring. This diatom bloom propagated south, leaving in its wake large diatoms that were silicic acid limited (Franck et al., 2000). The phytoplankton just north of the $\Delta \mathrm{Si}_{\text {max }}$ operate at a relatively low photosynthetic performance because the large diatoms are regulating on iron. This assemblage of phytoplankton would respond positively to iron additions early in the growing season. Later in summer, after the diatoms have reduced silicic acid to limiting concentrations, however, there is a community shift to small, eucaryotic phytoplankton with relatively high photosynthetic performance. This summer community will not respond to iron addition by developing a high biomass diatom bloom.

The recent SOIREE iron addition (Boyd and Abraham, 2001; Boyd and Law, 2001), however, did produce an iron-stimulated diatom bloom in the Antarctic Zone during the summer. The February 9, 1999 SOIREE iron addition at $61^{\circ} \mathrm{S}$, $140^{\circ} \mathrm{E}$ produced a significant increase in silicic acid drawdown (Frew et al., 2001; Gall et al., 2001a). In contrast, at a similar time (January 20, 1998) within the same oceanic zone as SOIREE (Antarctic Zone between the APF and SACCF, $62^{\circ} \mathrm{S}$, $\left.170^{\circ} \mathrm{W}\right)$, a JGOFS “on-deck" iron-enrichment experiment, did not result in increased silicic acid uptake by diatoms (Fig. 9) (Franck et al., 2000). This incongruity can be explained by the varying extent of the seasonal ice, which created different initial biological and chemical compositions at these locations.

In the JGOFS project along $170^{\circ} \mathrm{W}$, seasonal ice extended to just south of the APF (near $61^{\circ} \mathrm{S}$ ) (Smith et al., 2000b), and the JGOFS on-deck 
iron-addition experiment of Franck et al. (2000) was carried out in the SIZ. Winter ice cover and associated winter recharge of macronutrients (early spring silicic acid concentrations of $40 \mu \mathrm{M}$ ) and micronutrients, followed by the rapid spring retreat of the ice in the SIZ, provide a seasonal growth pulse during a period when mesozooplankton grazers remain in relatively low abundance. Low grazing pressure allows the accumulation of a dense diatom assemblage that sets in motion the southward-propagating $\Delta \mathrm{Si}_{\max }$ as the diatoms take up and export silicic acid. By January 20, 1998, the initial biomass was dominated by senescent large diatoms and healthy smaller phytoplankton, photosynthetic performance was high, and the silicic acid concentration was low $(<5 \mu \mathrm{M})$ (Fig. 9). Given this initial biomass of iron-replete small phytoplankton, the JGOFS "on-deck" ironenrichment site did not result in increased silicic acid uptake by diatoms (Fig. 9) (Franck et al., 2000).

However, at the SOIREE site, seasonal ice extended only to $62^{\circ} \mathrm{S}$, and the in situ iron addition (Boyd et al., 2000) was carried out in the Permanently Open Ocean Zone (POOZ), remote from the influence of sea ice (Trull et al., 2001). In the POOZ, there is less of a seasonal pulse of growth and little respite from grazing pressure. At the $140^{\circ} \mathrm{E}$ SOIREE site, because irradiance is unobstructed by ice and primary productivity proceeds at some level throughout the year, the winter nutrient recharge is dampened. Trull et al. (2001) report winter silicic acid concentrations of $22 \mu \mathrm{M}$. The spring diatom pulse evident at $170^{\circ} \mathrm{W}$ is absent at $140^{\circ} \mathrm{E}$; but at $140^{\circ} \mathrm{E}$ there is a continuous level of low productivity. As a result, there is a "balanced" food web of phytoplankton productivity and zooplankton grazing. By February 9, 1999, the initial biomass was a collection of pico-eukaryotes and viable diatoms, photosynthetic performance was low, and the silicic acid concentration was intermediate $(10 \mu \mathrm{M})$ (Boyd et al., 2000). In this quasiequilibrium state where growth is balanced by grazing, the ambient silicic acid $(10 \mu \mathrm{M})$ is sufficient for a significant diatom bloom even late in the austral growing season. That growth, however, is limited by iron and, as shown by
SOIREE, the phytoplankton assemblage in these waters responds positively to iron addition.

\section{Conclusions}

(a) There is a well-defined primary productivity maximum synchronized with seasonal irradiance:

- In austral early spring (October-November), during early bloom conditions, mean primary productivity was $33 \mathrm{mmol}$ $\mathrm{Cm}^{-2} \mathrm{~d}^{-1}$.

- In late spring (December), during bloom conditions, primary productivity averaged $67 \mathrm{mmol} \mathrm{Cm}^{-2} \mathrm{~d}^{-1}$, and absolute values ranged from 33 to $93 \mathrm{mmol}$ $\mathrm{Cm}^{-2} \mathrm{~d}^{-1}$ depending on station location.

- In late summer (February-March), during post-bloom conditions, mean primary productivity was $19 \mathrm{mmol} \mathrm{C} \mathrm{m}^{-2} \mathrm{~d}^{-1}$.

(b) While photosynthetic performance $\left(P_{\mathrm{opt}}^{\mathrm{B}}\right)$ showed a consistent inverse relationship with silicic acid concentration, it did not consistently covary with temperature or nitrate.

(c) In late summer, photosynthetic performance $\left(P_{\mathrm{opt}}^{\mathrm{B}}\right)$ varied directly with photochemical efficiency $\left(F_{\mathrm{v}} / F_{\mathrm{m}}\right)$ and with dissolved iron concentration, but varied inversely with photochemical efficiency response to iron enrichment.

(d) In late summer, iron concentration varied inversely with silicic acid concentration. The lowest iron concentrations were south of the Southern Boundary of the Antarctic Circumpolar Current (ACC) in the Subpolar Regime.

(e) Newly upwelled, iron-rich Upper Circumpolar Deep Water (UCDW) was present at the surface in both the Antarctic Zone and the Southern ACC Zone, but absent south of the Southern Boundary of the ACC in the Subpolar Regime and north of the Antarctic Polar Front (APF) in the Antarctic Polar Front Zone and the Subantarctic Zone (Figs. 2 and 11).

(f) We suggest that the winter recharge of UCDW within the Antarctic and Southern ACC Zones provides enough iron to support 
a diatom bloom that annually propagates poleward across the Antarctic and Southern ACC Zones to the Southern Boundary of the ACC, where the absence of iron-rich UCDW prevents the bloom's progression into the Subpolar Regime.

(g) Given the photosynthetic performance results presented here and the silicic acid limitation results presented in Franck et al. (2000), Nelson et al. (2001) and Sigmon et al. (2002), we suggest that there are three regions in the Southern Ocean that would respond differently to in situ iron addition:

- South of the Southern Boundary of the ACC and north of the continental margin, the Subpolar Regime was consistently silicic acid replete and iron limited; this suggests it would respond positively to iron addition throughout the growing season.

- Between the APF and the Southern Boundary of the ACC, the Seasonal Ice Zone was silicic acid replete and iron limited in early spring and became silicic acid limited and iron sufficient in summer; this suggests it would respond positively to iron enrichment in spring, but not in summer.

- The region north of the APF was silicic acid limited and iron sufficient in early spring; this suggests it would not develop a high biomass diatom bloom in response to iron addition.

\section{Acknowledgements}

Major support for this research was provided by the Harvey W. Smith Endowment at Duke University, by the National Science Foundation as part of the US JGOFS (NSF Grants OPP9530611 to JM, OPP-9531990 to WOS, OCE9530961 to CM, OPP-9530718 to RJO and HMS, and OPP-9531981 to RTB), and by NASA Grant NAG5-7538 to HMS. MRH was supported by a graduate fellowship from the American Meteorological Society and the NASA's "Mission to Planet Earth" program. We especially thank the crew of the Scripps Institution of Oceanography ship R/V Roger Revelle, radiation safety officer Sandy O'Brien, and members of the primary productivity team: Elaine Barber, Lisa Borden, Jonathan Borden, Sarah Goldthwaite, Anna Hilting, Zackary Johnson, Carol Knudsen, Brian Kulak, John Meadows and Jim Postell. We thank the Oregon State University optical mooring team for providing the essential irradiance data used in this paper and Lou Codispoti and John Morrison's team of technicians for nutrient and physical data. In particular, we gratefully acknowledge the help provided by the ASA logistics personnel in New Zealand. Thoughtful and critical reviews by an anonymous group, Kevin R. Arrigo, and Paul Tréguer, and painstaking editorial scrutiny by Ashley L. Simons, greatly aided our revisions. Lastly, we applaud guest editor Robert F. Anderson for his careful stewardship of this manuscript. This is JGOFS Contribution No. 765 and Virginia Institute of Marine Sciences Contribution No. 2460.

\section{References}

Abbott, M.R., Richman, J.G., Letelier, R.M., Bartlett, J.S., 2000. The spring bloom in the Antarctic Polar Frontal Zone as observed from a mesoscale array of bio-optical sensors. Deep-Sea Research II 47, 3285-3314.

Banse, K., 1996. Low seasonality of low concentrations of surface chlorophyll in the Subantarctic water ring: underwater irradiance, iron, or grazing? Progress in Oceanography 37, 241-291.

Barber, R.T., Sanderson, M.P., Lindley, S.T., Chai, F., Newton, J., Trees, C.C., Foley, D.G., Chavez, F.P., 1996. Primary productivity and its regulation in the equatorial Pacific during and following the 1991-1992 El Niño. DeepSea Research II 43, 933-969.

Barber, R.T., Borden, L., Johnson, Z., Marra, J., Knudson, C., Trees, C.C., 1997. Ground truthing modeled $k_{\mathrm{PAR}}$ and on deck primary productivity incubations with in situ observations. Society of Photo-Optical Instrumentation Engineers 2963, 834-839.

Bathmann, U.V., Scharek, R., Klaas, C., Dubischar, C.D., Smetacek, V., 1997. Spring development of phytoplankton biomass and composition in major water masses of the Atlantic sector of the Southern Ocean. Deep-Sea Research II 44, 51-67.

Behrenfeld, M.J., Falkowski, P.G., 1997. Photosynthetic rates derived from satellite-based chlorophyll concentration. Limnology and Oceanography 42, 1-20. 
Boyd, P.W., Abraham, E.R., 2001. Iron-mediated changes in phytoplankton photosynthetic competence during SOIREE. Deep-Sea Research II 48, 2529-2550.

Boyd, P.W., Law, C.S., 2001. The Southern Ocean Iron RElease Experiment (SOIREE) - introduction and summary. Deep-Sea Research II 48, 2425-2438.

Boyd, P.W., Watson, A.J., Law, C.S., Abraham, E.R., Trull, T., Murdoch, R., Bakker, D.C.E., Bowie, A.R., Buesseler, K.O., Chang, H., Charette, M., Croot, P., Downing, K., Frew, R., Gall, M., Hadfield, M., Hall, J., Harvey, M., Jameson, G., LaRoche, J., Liddicoat, M., Ling, R., Maldonado, M.T., McKay, R.M., Nodder, S., Pickmere, S., Pridmore, R., Rintoul, S., Safi, K., Sutton, P., Strzepek, R., Tanneberger, K., Turner, S., Waite, A., Zeldis, J., 2000. A mesoscale phytoplankton bloom in the polar Southern Ocean stimulated by iron fertilization. Nature 407, 695-702.

Bradford-Grieve, J.M., Chang, F.H., Gall, M., Pickmere, S., Richards, F., 1997. Size-fractionated phytoplankton standing stocks and primary production during austral winter and spring 1993 in the Subtropical Convergence region near New Zealand. New Zealand Journal of Marine and Freshwater Research 31, 201-224.

Broecker, W.S., 1982. Glacial to interglacial changes in ocean chemistry. Progress in Oceanography 11, 151-197.

Brown, S.L., Landry, M.R., 2001a. Microbial community structure and biomass in surface waters during a Polar Front summer bloom along $170^{\circ} \mathrm{W}$. Deep-Sea Research II 48, 4039-4058.

Brown, S.L., Landry, M.R., 2001b. Mesoscale variability in biological community structure and biomass in the Antarctic Polar Front region at $170^{\circ} \mathrm{W}$ during austral spring 1997. Journal of Geophysical Research 106, 13917-13930.

Brzezinski, M.A., Nelson, D.M., Franck, V.M., Sigman, D.E., 2001. Silicon dynamics within an intense open-ocean diatom bloom in the Pacific sector of the Southern Ocean. Deep-Sea Research II 48, 3997-4018.

Burkholder, P.R., Burkholder, L.M., 1967. Primary productivity in surface waters of the South Pacific Ocean. Limnology and Oceanography 12, 606-617.

Callahan, J.E., 1972. The structure and circulation of Deep Water in the Antarctic. Deep-Sea Research 19, 563-575.

Currie, R.I., 1964. Environmental features in the ecology of Antarctic seas. In: Carrick, R., Holdgate, M., Prévost, J. (Eds.), Biologie Antarctique. Hermann, Paris, pp. 87-94.

Cushing, D.H., 1981. Temporal variability in production systems. In: Longhurst, A.R. (Ed.), Analysis of Marine Ecosystems. Academic Press, New York, pp. 443-471.

Daly, K.L., Smith Jr., W.O., Johnson, G.C., DiTullio, G.R., Jones, D.R., Mordy, C.W., Feely, R.A., Hansell, D.A., Zhang, J.-Z., 2001. Hydrography, nutrients, and carbon pools in the Pacific sector of the Southern Ocean: implications for carbon flux. Journal of Geophysical Research 106, 7107-7124.

de Baar, H.J.W., de Jong, J.T.M., Bakker, D.C.E., Löscher, B.M., Veth, C., Bathmann, U., Smetacek, V., 1995. Importance of iron for plankton blooms and carbon dioxide drawdown in the Southern Ocean. Nature 373, 412-415.
El-Sayed, S.Z., Taguchi, S., 1981. Primary production and standing crop of phytoplankton along the ice-edge in the Weddell Sea. Deep-Sea Research 28, 1017-1032.

Erdner, D.L., Anderson, D.M., 1999. Ferredoxin and flavodoxin as biochemical indicators of iron limitation during open-ocean iron enrichment. Limnology and Oceanography 44, 1609-1615.

Evans, G.T., Parslow, J.S., 1985. A model of annual plankton cycles. Biological Oceanography 3, 327-347.

Fitzwater, S.E., Coale, K.H., Gordon, R.M., Johnson, K.S., Ondrusek, M.E., 1996. Iron deficiency and phytoplankton growth in the equatorial Pacific. Deep-Sea Research II 43, 995-1015.

Fogg, G.E., 1977. Aquatic primary production in the Antarctic. Philosophical Transactions of the Royal Society of London, Series B 279, 27-38.

Franck, V.M., Brzezinski, M.A., Coale, K.H., Nelson, D.M., 2000. Iron and silicic acid concentrations regulate Si uptake north and south of the Polar Frontal Zone in the Pacific sector of the Southern Ocean. Deep-Sea Research II 47, 3315-3338.

Francois, R., Altabet, M.A., Yu, E.F., Sigman, D.M., Bacon, M.P., Frank, M., Bohrmann, G., Bareille, G., Labeyrie, L.D., 1997. Contribution of Southern Ocean surface-water stratification to low atmospheric $\mathrm{CO}_{2}$ concentrations during the last glacial period. Nature 389, 929-935.

Frew, R., Bowie, A., Croot, P., Pickmere, S., 2001. Macronutrient and trace-metal geochemistry of an in situ ironinduced Southern Ocean bloom. Deep-Sea Research II 48, 2467-2481.

Gall, M.P., Strzepek, R., Maldonado, M., Boyd, P.W., 2001a. Phytoplankton processes. Part 2: Rates of primary production and factors controlling algal growth during the Southern Ocean Iron RElease Experiment (SOIREE). Deep-Sea Research II 48, 2571-2590.

Gall, M.P., Boyd, P.W., Hall, J., Safi, K.A., Chang, H., 2001 b. Phytoplankton processes. Part 1: Community structure during the Southern Ocean Iron RElease Experiment (SOIREE). Deep-Sea Research II 48, 2551-2570.

Goericke, R., Repeta, D.J., 1993. Chlorophylls $a$ and $b$ and divinyl chlorophylls $a$ and $b$ in the open subtropical North Atlantic Ocean. Marine Ecology Progress Series 101, 307-313.

Gregg, W.W., Carder, K.L., 1990. A simple spectral solar irradiance model for cloudless maritime atmospheres. Limnology and Oceanography 35, 1657-1675.

Hart, J.T., 1942. Phytoplankton periodicity in Antarctic surface waters. Discovery Reports 21, 261-356.

Holm-Hansen, O., Lorenzen, C.J., Holmes, R.W., Strickland, J.D.H., 1965. Fluorometric determination of chlorophyll. Journal du Conseil 30, 3-15.

Holm-Hansen, O., El-Sayed, S.Z., Franceschini, G.A., Cuhel, R.L., 1977. Primary production and the factors controlling phytoplankton growth in the Southern Ocean. In: Llano, G.A. (Ed.) Adaptations within the Antarctic Ecosystems. Proceedings of the third SCAR Symposium on Antarctic Biology. Smithsonian Institution, Washington, DC, pp. 11-50. 
Hoppema, M., Fahrbach, E., de Baar, H.J.W., 2000. Surface layer balance of the southern Antarctic Circumpolar Current (prime meridian) used to derive carbon and silicate consumptions and annual air-sea exchange for $\mathrm{CO}_{2}$ and oxygen. Journal of Geophysical Research 105, $11359-11371$.

Hunter, C.N., Gordon, R.M., Fitzwater, S.E., Coale, K.H., 1996. A rosette system for the collection of trace metal clean seawater. Limnology and Oceanography 41, 1367-1372.

Huntsman, S.A., Barber, R.T., 1977. Primary production off northwest Africa: the relationship to wind and nutrient conditions. Deep-Sea Research 24, 25-33.

Jacques, G., 1989. Primary production in the open Antarctic Ocean during the austral summer. A review. Vie Milieu 39, $1-17$.

Jacques, G., Minas, M., 1981. Primary productivity in the Indian sector of the Antarctic Ocean during late summer. Oceanologica Acta 4, 33-41.

Joos, F., Siegenthaler, U., Sarmiento, J.L., 1991. Possible effects of iron fertilization in the Southern Ocean on atmospheric $\mathrm{CO}_{2}$ concentration. Global Biogeochemical Cycles 5, 135-150.

Keeling, R.F., Visbeck, M., 2001. PalaeoceanographyAntarctic stratification and glacial $\mathrm{CO}_{2}$. Nature 412, 605-606.

Kirk, J.T.O., 1996. Light and Photosynthesis in Aquatic Ecosystems. Cambridge University Press, Bristol, 509pp.

Knox, F., McElroy, M.B., 1984. Changes in atmospheric $\mathrm{CO}_{2}$ : influence of the marine biota at high latitude. Journal of Geophysical Research 89, 4629-4637.

Kolber, Z.S., Barber, R.T., Coale, K.H., Fitzwater, S.E., Greene, R.M., Johnson, K.S., Lindley, S., Falkowski, P.G., 1994. Iron limitation of phytoplankton photosynthesis in the equatorial Pacific Ocean. Nature 371, 145-149.

Kolber, Z.S., Prášil, O., Falkowski, P.G., 1998. Measurements of variable chlorophyll fluorescence using fast repetition rate techniques: defining methodology and experimental protocols. Biochimica et Biophysica Acta 1367, 88-106.

Kurz, K.D., Maier-Reimer, E., 1993. Iron fertilization of the austral ocean - the Hamburg model assessment. Global Biogeochemical Cycles 7, 229-244.

Landry, M.R., Barber, R.T., Bidigare, R.R., Chai, F., Coale, K.H., Dam, H.G., Lewis, M.R., Lindley, S.T., McCarthy, J.J., Roman, M.R., Stoecker, D.K., Verity, P.G., White, J.R., 1997. Iron and grazing constraints on primary production in the central equatorial Pacific: an EqPac synthesis. Limnology and Oceanography 42, 405-418.

Landry, M.R., Brown, S.L., Selph, K.E., Abbott, M.R., Letelier, R.M., Christensen, S., Bidigare, R.R., Casciotti, K., 2001. Initiation of the spring phytoplankton increase in the Antarctic Polar Front Zone at $170^{\circ} \mathrm{W}$. Journal of Geophysical Research 106, 13903-13915.

Lewis, M.R., Smith, J.C., 1983. A small volume, shortincubation-time method for measurement of photosynthesis as a function of incident irradiance. Marine Ecology Progress Series 13, 99-102.
Lindley, S.T., Bidigare, R.R., Barber, R.T., 1995. Phytoplankton photosynthesis parameters along $140^{\circ} \mathrm{W}$ in the equatorial Pacific. Deep-Sea Research II 42, 441-463.

Longhurst, A., 1998. Ecological Geography of the Sea. Academic Press, San Diego, 398pp.

Lorenzen, C.J., 1966. A method for the continuous measurement of in vivo chlorophyll concentration. Deep-Sea Research 13, 223-227.

Löscher, B.M., 1999. Relationships among $\mathrm{Ni}, \mathrm{Cu}, \mathrm{Zn}$, and major nutrients in the Southern Ocean. Marine Chemistry 67, 67-102.

Löscher, B.M., de Baar, H.J.W., de Jong, J.T.M., Veth, C., Dehairs, F., 1997. The distribution of $\mathrm{Fe}$ in the Antarctic Circumpolar Current. Deep-Sea Research II 44, 143-187.

Lutjeharms, J.R.E., Walters, N.M., Allanson, B.R., 1985. Oceanic frontal systems and biological enhancement. In: Siegfried, W.R., Condy, P.R., Laws, R.M. (Eds.), Antarctic Nutrient Cycles and Food Webs. Springer, Berlin, pp. 11-21.

Martin, J.H., 1990. Glacial-interglacial $\mathrm{CO}_{2}$ change: the iron hypothesis. Paleoceanography 5, 1-13.

Martin, J.H., Gordon, R.M., Fitzwater, S.E., 1990. Iron in Antarctic waters. Nature 345, 156-158.

Measures, C.I., Vink, S., 2001. Dissolved Fe in the upper waters of the Pacific sector of the Southern Ocean. Deep-Sea Research II 48, 3913-3941.

Measures, C.I., Yuan, J., Resing, J.A., 1995. Determination of iron in seawater by flow injection analysis using in-line preconcentration and spectrophotometric detection. Marine Chemistry 50, 3-12.

Mitchell, B.G., Holm-Hansen, O., 1991. Observations and modeling of the Antarctic phytoplankton crop in relation to mixing depth. Deep-Sea Research 38, 981-1007.

Moore, J.K., Abbott, M.R., 2000. Phytoplankton chlorophyll distributions and primary production in the Southern Ocean. Journal of Geophysical Research 105, 28709-28722.

Moore, J.K., Abbott, M.R., Richman, J.R., Nelson, D.M., 2000. The Southern Ocean at the last glacial maximum: a strong sink for atmospheric carbon dioxide. Global Biogeochemical Cycles 14, 455-475.

Morel, A., 1988. Optical modeling of the upper ocean in relation to its biogenous matter content (Case I waters). Journal of Geophysical Research 93, 10749-10768.

Morel, A., 1991. Light and marine photosynthesis: a spectral model with geochemical and climatological implications. Progress in Oceanography 26, 263-306.

Morel, F.M.M., Hudson, R.J.M., Price, N.M., 1991a. Limitation of productivity by trace-metals in the sea. Limnology and Oceanography 36, 1742-1755.

Morel, F.M.M., Rueter, J.G., Price, N.M., 1991b. Iron nutrition of phytoplankton and its possible importance in the ecology of ocean regions with high nutrient and low biomass. Oceanography 4, 56-61.

Morrison, J.M., Gaurin, S., Codispoti, L.A., Takahashi, T., Millero, F.J., Gardner, W.D., Richardson, M.J., 2001. Seasonal evolution of the hydrographic properties in the 
Antarctic circumpolar current at $170^{\circ} \mathrm{W}$ during $1997-1998$. Deep-Sea Research II 48, 3943-3972.

Nelson, D.M., Smith Jr., W.O., 1991. Sverdrup revisited: critical depths, maximum chlorophyll levels, and the control of southern ocean productivity by the irradiance-mixing regime. Limnology and Oceanography 36, 1650-1661.

Nelson, D.M., Tréguer, P., 1992. Role of silicon as a limiting nutrient to Antarctic diatoms: evidence from kinetic studies in the Ross Sea ice-edge zone. Marine Ecology Progress Series 80, 255-264.

Nelson, D.M., Brzezinski, M.A., Sigman, D.E., Franck, V.M., 2001. A seasonal progression of Si limitation in the Pacific sector of the Southern Ocean. Deep-Sea Research II 48, 3973-3995.

Olson, R.J., Sosik, H.M., Chekalyuk, A.M., Shalapyonok, A., 2000. Effects of iron enrichment on phytoplankton in the Southern Ocean during late summer: active fluorescence and flow cytometric analyses. Deep-Sea Research II 47, 3181-3200.

Orsi, A.H., Whitworth III, T., Nowlin Jr., W.D., 1995. On the meridional extent and fronts of the Antarctic Circumpolar Current. Deep-Sea Research 42, 641-673.

Park, Y.H., Gamberoni, L., Charriaud, E., 1993. Frontal structure, water masses, and circulation in the Crozet Basin. Journal of Geophysical Research 98, 12361-12385.

Patterson, S.L., Whitworth, T., 1990. Physical oceanography. In: Glasby, G.P. (Ed.), Antarctic Sector of the Pacific. Elsevier, New York, pp. 55-93.

Peng, T.H., Broecker, W.S., 1991. Factors limiting the reduction of atmospheric $\mathrm{CO}_{2}$ by iron fertilization. Limnology and Oceanography 36, 1919-1927.

Platt, T., Gallegos, C.L., Harrison, W.G., 1980. Photoinhibition of photosynthesis in natural assemblages of marine phytoplankton. Journal of Marine Research 38, 687-701.

Pollard, R.T., Read, J.F., Allen, J.T., Griffiths, G., Morrison, A.I., 1995. On the physical structure of a front in the Bellingshausen Sea. Deep-Sea Research II 42, 955-982.

Prézelin, B.B., Hofmann, E.E., Mengelt, C., Klinck, J.M., 2000. The linkage between Upper Circumpolar Deep Water (UCDW) and phytoplankton assemblages on the west Antarctic Peninsula continental shelf. Journal of Marine Research 58, 165-202.

Price, N.M., Ahner, B.A., Morel, F.M.M., 1994. The equatorial Pacific Ocean: grazer-controlled phytoplankton populations in an iron-limited ecosystem. Limnology and Oceanography $39,520-534$.

Ramus, J., 1985. Light. In: Littler, M.M., Littler, D.S. (Eds.), Handbook of Phycological Methods. Ecological Field Methods: Macroalgae. Cambridge University Press, Cambridge, pp. 33-51.

Ryther, J.H., 1963. Geographic variations in productivity. In: Hill, M.N. (Ed.), The Sea. Wiley, New York, pp. 347-380.

Sakshaug, E., Bricaud, A., Dandonneau, Y., Falkowski, P.G., Kiefer, D.A., Legendre, L., Morel, A., Parslow, J., Takahashi, M., 1997. Parameters of photosynthesis: definitions, theory and interpretation of results. Journal of Plankton Research 19, 1637-1670.
Sarmiento, J.L., Orr, J.C., 1991. 3-Dimensional simulations of the impact of Southern Ocean nutrient depletion on atmospheric $\mathrm{CO}_{2}$ and ocean chemistry. Limnology and Oceanography 36, 1928-1950.

Sarmiento, J.L., Toggweiler, J.R., 1984. A new model for the role of the oceans in determining atmospheric $P_{\mathrm{CO} 2}$. Nature 308, 621-624.

Siegenthaler, U., Wenk, Th., 1984. Rapid atmospheric $\mathrm{CO}_{2}$ variations and ocean circulation. Nature 308, 624-626.

Sigman, D.M., Boyle, E.A., 2000. Glacial/interglacial variations in atmospheric carbon dioxide. Nature 407, 859-869.

Sigman, D.M., Boyle, E.A., 2001. Palaeoceanography-Antarctic stratification and glacial $\mathrm{CO}_{2}-$ Sigman and Boyle reply. Nature 412, 606.

Sigmon, D.E., Nelson, D.M., Brzezinski, M.A., 2002. The Si cycle in the Pacific sector of the Southern Ocean: seasonal diatom production in the surface layer and export to the deep sea. Deep-Sea Research II 49, 1747-1763.

Smith, W.O., Nelson, D.M., 1985. Phytoplankton bloom produced by a receding ice edge in the Ross Sea: spatial coherence with the density field. Science 227, 163-166.

Smith Jr., W.O., Marra, J., Hiscock, M.R., Barber, R.T., 2000a. The seasonal cycle of phytoplankton biomass and primary productivity in the Ross Sea, Antarctica. Deep-Sea Research II 47, 3119-3140.

Smith Jr., W.O., Anderson, R.F., Moore, J.K., Codispoti, L.A., Morrison, J.M., 2000b. The US Southern Ocean Joint Global Ocean Flux Study: an introduction to AESOPS. Deep-Sea Research II 47, 3073-3093.

Sosik, H.M., Olson, R.J., 2002. Phytoplankton and iron limitation of photosynthetic efficiency in the Southern Ocean during late summer. Deep-Sea Research 49, 1195 1216.

Steele, J.H., Henderson, E.W., 1992. The role of predation in plankton models. Journal of Plankton Research 14, $157-172$.

Stephens, B.B., Keeling, R.F., 2000. The influence of Antarctic Sea ice on glacial-interglacial $\mathrm{CO}_{2}$ variations. Nature 404, $171-174$

Sullivan, C.W., Arrigo, K.R., McClain, C.R., Comiso, J.C., Firestone, J., 1993. Distributions of phytoplankton blooms in the Southern Ocean. Science 262, 1832-1837.

Sunda, W.G., Huntsman, S.A., 1995. Iron uptake and growth limitation in oceanic and coastal phytoplankton. Marine Chemistry 50, 189-206.

Sverdrup, H.U., 1953. On conditions for the vernal blooming of phytoplankton. Journal du Conseil 18, 287-295.

Timmermans, K.R., Gerringa, L.J.A., de Baar, H.J.W., van der Wagt, B., Veldhuis, M.J.W., de Jong, J.T.M., Croot, P.L., 2001. Growth rates of large and small Southern Ocean diatoms in relation to availability of iron in natural seawater. Limnology and Oceanography 46, 260-266.

Toggweiler, J.R., Sarmiento, J.L., 1985. Glacial to interglacial changes in atmospheric carbon dioxide: the critical role of ocean surface water in high latitudes. In: Sundquist, E.T., Broecker, W.S. (Eds.), Natural Variations Archean to 
Present, Geophysical Monograph 32. AGU, Washington, DC, pp. 163-184.

Tréguer, P., Jacques, G., 1992. Dynamics of nutrients and phytoplankton, and fluxes of carbon, nitrogen and silicon in the Antarctic Ocean. Polar Biology 12, 149-162.

Trull, T., Rintoul, S.R., Hadfield, M., Abraham, E.R., 2001. Circulation and seasonal evolution of polar waters south of Australia: implications for iron fertilization of the southern ocean. Deep-Sea Research II 48, 2439-2466.

Tynan, C.T., 1998. Ecological importance of the Southern Boundary of the Antarctic Circumpolar Current. Nature 392, 708-710.

Venrick, E.L., Hayward, T.L., 1984. Determining chlorophyll on the 1984 CalCOFI surveys. California Cooperative Oceanic Fisheries Investigation Report 25, 74-79.
Veth, C., Peeken, I., Scharek, R., 1997. Physical anatomy of fronts and surface waters in the ACC near the $6^{\circ} \mathrm{W}$ meridian during austral spring 1992. Deep-Sea Research II 44, 23-49.

Watson, A.J., Bakker, D.C.E., Ridgwell, A.J., Boyd, P.W., Law, C.S., 2000. Effect of iron supply on Southern Ocean $\mathrm{CO}_{2}$ uptake and implications for glacial atmospheric $\mathrm{CO}_{2}$. Nature 407, 730-733.

Whitworth III, T., Nowlin Jr., W.D., 1987. Water masses and currents of the Southern Ocean at the Greenwich Meridian. Journal of Geophysical Research 92, 6462-6476.

Zentara, S.-J., Kamykowski, D., 1981. Geographic variations in the relationship between silicic acid and nitrate in the South Pacific Ocean. Deep-Sea Research 28, 455-465. 